\title{
Neurosteroids Modulate Calcium Currents in Hippocampal CA1 Neurons via a Pertussis Toxin-Sensitive G-Protein-coupled Mechanism
}

\author{
Jarlath M. H. ffrench-Mullen, Petra Danks, and Katherine T. Spence \\ Department of Pharmacology, Zeneca Pharmaceuticals Group, Zeneca Inc., Wilmington, Delaware 19897
}

The inhibition of $\mathrm{Ca}^{2+}$ channel currents by endogenous brain steroids was examined in freshly dissociated pyramidal neurons from the adult guinea pig hippocampal CA1 region. The steady-state inhibition of the peak $\mathrm{Ca}^{2+}$ channel current evoked by depolarizing steps from -80 to $-10 \mathrm{mV}$ occurred in a concentration-dependent manner with the following ${ } C_{50}$ values: pregnenolone sulfate (PES), $11 \mathrm{~nm}$; pregnenolone (PE), $130 \mathrm{nM}$; and allotetrahydrocorticosterone (THCC), 298 nM. THCC, PE, and PES depressed a fraction of the $\mathrm{Ca}^{2+}$ channel current with a maximal inhibition of $60 \%$ of the total current. However, substitution of an acetate group for the sulfate group on PES resulted in a complete loss of activity. Progesterone had no effect (4\% inhibition at $100 \mu \mathrm{M})$. Intracellular dialysis of PES had no effect on the $\mathrm{Ca}^{2+}$ current; concomitant extracellular perfusion of PES showed normal inhibitory activity, suggesting that the steroid binding site can only be accessed extracellularly. Analysis of tail currents at $-80 \mathrm{mV}$ demonstrated that THCC and PES slowed the rate of $\mathrm{Ca}^{2+}$ current activation and deactivation with no change in the voltage dependence of activation. Inhibition of the $\mathrm{Ca}^{2+}$ channel current by THCC and PES was voltage dependent. THCC primarily inhibits the $\omega$-conotoxin (CgTX)sensitive or $\mathrm{N}$-type $\mathrm{Ca}^{2+}$ channel current. PE was nonselective in inhibiting both the $\mathrm{CgTX}$ - and the nifedipine (NIF)sensitive $\mathrm{Ca}^{2+}$ channel current. These neurosteroids had no effect on the CgTX/NIF-insensitive current.

In neurons isolated from pertussis toxin (PTX)-treated animals by chronic intracerebroventricular infusion (1000 ng/ $24 \mathrm{hr}$ for $48 \mathrm{hr}$ ), the $\mathrm{Ca}^{2+}$ channel current inhibition by PES, $P E$, and THCC was significantly diminished. Intracellular dialysis with GDP- $\beta$-S (500 $\mu \mathrm{M})$ also significantly diminished the neurosteroid inhibition of the $\mathrm{Ca}^{2+}$ channel current. Intracellular dialysis with the general kinase inhibitors $\mathrm{H}-7$ (100 $\mu \mathrm{M})$, staurosporine (400 $\mathrm{nm}$ ), and a 20 amino acid protein kinase inhibitor ( $1 \mu \mathrm{M})$ also significantly prevented the THCC and PES inhibition of the $\mathrm{Ca}^{2+}$ channel current. Intracellular dialysis with the more specific inhibitors of protein kinase $\mathrm{C}$ (PKC), the pseudosubstrate inhibitor (PKCl 19-36) (1-2 $\mu \mathrm{M}$ ) and bisindolylmaleimide (1 $\mu \mathrm{M})$ significantly diminished the THCC and PE inhibition of the $\mathrm{Ca}^{2+}$ channel current. Rp-

\footnotetext{
Received Mar. 18, 1993; revised Sept. 1, 1993; accepted Sept 14, 1993.

We thank Dr. C. R. Plata-Salamán for his assistance with the pertussis toxin experiments.

Correspondence should be addressed to J. M. H. ffrench-Mullen, Ph.D., Department of Pharmacology, Zeneca Pharmaceuticals Group, Zeneca Inc., Wilmington, DE 19897.

Copyright (C) 1994 Society for Neuroscience $0270-6474 / 94 / 141963-15 \$ 05.00 / 0$
}

CAMPS $(100 \mu \mathrm{M})$, a specific inhibitor of CAMP-dependent protein kinase (PKA), had no effect on the THCC and PE inhibition of the $\mathrm{Ca}^{2+}$ current. These results demonstrate that neurosteroids, acting at a membrane receptor site, are potent modulators of either the $\mathrm{CgTX}$ - and/or the NIF-sensitive $\mathrm{Ca}^{2+}$ channel current but not the $\mathrm{CgTX} / \mathrm{NIF}$-insensitive current. Furthermore, the $\mathrm{Ca}^{2+}$ channel current inhibition is via a PTX-sensitive G-protein-coupled mechanism associated with the activation of PKC. Thus, inhibition of $\mathrm{Ca}^{2+}$ channel currents by neurosteroids may participate in the regulation of synaptic processes such as modulation of neuronal activity and/or neurotransmitter release-associated mechanisms via a G-protein mechanism(s).

[Key words: calcium channel, neurosteroid, G-protein, protein kinase $C, \omega$-conotoxin, nifedipine, hippocampus, patch clamp]

The presence and action of steroids, both endogenous and synthetic, in the mammalian CNS are well documented. Steroids exert both genomic and nongenomic effects on cells, the latter reported as a direct action on neural membranes that is independent of the effects of nuclear transcription (McEwen, 1991). Certain steroids and their sulfate derivatives, the neurosteroids, are synthesized de novo in brain from cholesterol, primarily in oligodendrocytes (Baulieu and Robel, 1990). These neurosteroids may accumulate in the brain and serve as precursors to other steroids and their metabolites, and can be released in concentrations up to approximately $0.1 \mu \mathrm{M}$ (Corpcchot ct al., 1983; Lanthier and Patwardham, 1986). The neurosteroids that were originally discovered and characterized were pregnenolone (5-pregnen-3 $\beta$-ol-20-one, PE), dehydroepiandrosterone (5-androsten-3 $\beta$-ol-17-one), and their sulfate derivatives, pregnenolone sulfate (5-pregnen-3 $\beta$-ol-20-one-sulfate, PES) and dehydroepiandrosterone sulfate (5-androsten-3 $\beta$-ol-17-one-sulfate) (Corpéchot et al., 1981, 1983). PE can be transformed into progesterone, which in turn can be partially converted into $5 \alpha$ reduced metabolites in glial cells (Jung-Testas et al., 1989). Biochemical, electrophysiological, and behavioral evidence suggests a neuromodulatory role for steroids in the CNS (neuroactive steroids), particularly a bimodal regulation of certain neurotransmitter receptors. The ability of certain steroids and their metabolites to influence brain activity including the firing rate of neurons, induction of sedation, anesthesia, neurosecretion, and behavioral changes is well known (see McEwen, 1991). Considerable evidence exists indicating a stereoselective interaction (potentiation or antagonism) of structurally different steroids with the $\mathrm{GABA}_{\mathrm{A}}$ receptor without altering the reversal 
potential or conductance of the $\mathrm{GABA}$ receptor $\mathrm{Cl}^{-}$channel. In addition, certain steroids appear to modulate other ligand-gated currents. PES antagonizes the GABA-activated (Mienville and Vicini, 1989) and glycine-activated (Wu et al., 1990) $\mathrm{Cl}^{-}$currents and enhances the NMDA-gated current (Wu et al., 1991; Bowlby, 1993) and the NMDA receptor-mediated increase in intracellular $\mathrm{Ca}^{2+}$ (Irwin et al., 1992) in cultured neurons. PES increases the firing rate of septo-preoptic neurons (Carette and Poulain, 1984) and increases the convulsant potency of NMDA in mice (Maione et al., 1992).

Hippocampal pyramidal neurons possess multiple types of high-threshold $\mathrm{Ca}^{2+}$ channels classified into various subtypes on the basis of their electrophysiological and pharmacolngical properties (Fisher et al., 1990; Mogul and Fox, 1991; O'Dell and Alger, 1991; Regan et al., 1991; Mintz et al., 1992). The high-voltage-activated (HVA) whole-cell $\mathrm{Ca}^{2}+$ channel current is pharmacologically separated into the $\omega$-conotoxin (GVIA; CgTX) or N-type current, the dihydropyridine (e.g., nifedipine, NIF) or L-type current, and a fraction of current insensitive or resistant to both $\mathrm{CgTX}$ and NIF (Mogul and Fox, 1991; Regan et al., 1991; Mintz et al., 1992) but sensitive to $\omega$-agatoxin-IVA, the P-type current (Mintz et al., 1992). It has been suggested that the $\mathrm{CgTX}$-sensitive voltage-gated $\mathrm{Ca}^{2}+$ channel may play a critical role in the control of neurotransmitter release (see Miller, 1987; Dutar et al., 1989; Sher and Clementi, 1991).

Guanine nucleotide proteins (G-proteins) appear to regulate many cellular processes, including the regulation of ion channcls and neurotransmitter release (see Hille, 1992). Several neurotransmitters such as ACh, GABA, norepinephrine, opioids (for review, see Dolphin, 1990), and glutamate (Swartz and Bean, 1992) and several presynaptic receptors including $A_{1}$ adenosine, $\alpha_{2}$-adrenergic and GABA $_{13}$ (Lipscombe et al., 1989; Scholz and Miller, 1991) are known to reduce $\mathrm{Ca}^{2-}$ currents. Evidence suggests that this reduction of $\mathrm{Ca}^{2+}$ currents is through surface receptors coupled to the $\mathrm{Ca}^{2+}$ channel via a $\mathrm{G}$-protein-dependent mechanism that may be direct (in a membrane-delimited manner; Brown and Birnbaumer, 1988) or via intracellular mediators (for review, see Hille, 1992). The involvement of protein kinase $\mathrm{C}(\mathrm{PKC})$ in transmitter-mediated modulation of neuronal calcium channels also is indicated in many cell types (Hille, 1992; Diversé-Pierluissi and Dunlap, 1993).

In preliminary observations, we found that the neurosteroids allotetrahydrocorticosterone (THCC), PES, and PE inhibited the voltage-gated $\mathrm{Ca}^{2+}$ channels in neurons acutely isolated from the CAl region of the guinea pig hippocampus (ffrench-Mullen and Spence, 1991; Spence et al., 1991). In this study, we further clarify the inhibition of these neurosteroids on the voltage-gated $\mathrm{Ca}^{2+}$ channel currents in these neurons, and characterized their pharmacological profile and mechanism of action. We also demonstrate that these neurosteroids inhibit a fraction of the wholecell $\mathrm{Ca}^{2-}$ current via PTX-sensitive G-protein(s) and activation of $\mathrm{PKC}$.

\section{Materials and Methods}

Implantation of brain cannulas. Brain cannulas were implanted after several days of adaptation of the guinea pigs to their home cages as previously described (Plata-Salamán, 1992). Under intraperitoneal anesthesia (sodium pentobarbital, $30-45 \mathrm{mg} / \mathrm{kg}$ ), a small hole was made in the skull with an electric drill. Three other holes were made to fasten three jeweler's screws into the skull that were used to anchor the cannula with dental acrylic. A guide cannula of 23-gauge stainless steel tubing ( $18.0 \mathrm{~mm}$ long, $0.64 \mathrm{~mm}$ o.d., $0.39 \mathrm{~mm}$ i.d.; with a ball of solder located at $10 \mathrm{Im}$ m) was centered over the middle of the superior sagital sinus under microscope. Using a dural hook, an incision was made through the dura, the superior sagittal sinus was carefully pulled, and the guide cannula was gently lowered. The implantation of the guide cannula into the third ventricle was at stereotaxic coordinates AP $-1.7 \mathrm{~mm}, \mathrm{~L} 0.0$ with respect to the bregma, and $\mathrm{H} 8.5-9.0 \mathrm{~mm}$ from the brain surface. This technique minimizes cortical damage because the guide cannula is lowered vertically through the longitudinal fissure. The position of the tip of the guide cannula in the third ventricle was verified by the free outflow of cerebrospinal fluid through the cannula. A piece of Gelfoam was placed around the penetration sitc and dental acrylic was used to anchor the cannula. A sterile 29-gauge stainless steel obturator with a polyethylene cap $(18 \mathrm{~mm}$ long, $0.33 \mathrm{~mm}$ o.d.) flush with the tip of the guide cannula was used to ensure that the cannula remained patent. Guinea pigs were allowed to recover for 7-10 d after surgery before osmotic minipump implantation.

Implantation of osmotic minipumps. Alzet osmotic minipumps (Alza Corp., CA) were used to accomplish the continuous intracerebroventricular microinfusion of pertussis toxin (PTX; $1000 \mathrm{ng} / 24 \mathrm{hr}$ for 48 $\mathrm{hr}$ ). The nominal pumping rate of the osmotic minipumps is $1 \mu 1 / \mathrm{hr} / 7$ d (model 2001). For minipump implantation, the guinea pigs were anesthetized with sodium pentobarbital. The filled minipump was connected, by a short polyethylene tube $(1.1 \mathrm{~mm}$ i.d.), to an insert cannula of 29-gauge stainless steel tubing, L-shaped so that when inserted into the guide cannula its terminal end just reached the tip of the guide cannula. The minipump was inserted into the subcutaneous interscapular space, and the L-shaped steel tubing was cemented in place with dental acrylic.

Cell preparation. Pyramidal neurons were acutely isolated from the CAl region of the mature guinea pig hippocampus as previously described (ffrench-Mullen and Rogawski, 1992; ffrench-Mullen et al., 1993) and immediately used in electrophysiological experiments.

Whole-cell, patch-clamp recording. Macroscopic whole-cell $\mathrm{Ca}^{2+}$ channel currents were recorded at room temperature $\left(22-25^{\circ} \mathrm{C}\right)$ using 3 $\mathrm{mM} \mathrm{Ba}^{2}$ as the external charge-carrying divalent cation, and with the $\mathrm{Ca}^{2+}$ chelator $\mathrm{CS}_{4}$-BAPTA (Molecular Probes, Eugene, OR) in the intracellular solution to reduce $\mathrm{Ca}^{2-}$-promoted $\mathrm{Ca}^{2+}$ channel inactivation (Eckert and Chad, 1984). The bath solution contained (in $\mathrm{mm}$ ) $\mathrm{BaCl}_{2}$, 3; tetraethylammonium chloride, $140 ; \mathrm{MgCl}_{2}, 1$; HEPES, 10 ; and glucose, 6 . Tetrodotoxin $(2 \mu \mathrm{M})$ was added to the bath solution to inhibit voltage-dependent $\mathrm{Na}^{+}$channels, and the solution was adjusted to a $\mathrm{pH}$ of 7.4 with fresh $\mathrm{CsOH}$ solution and to an osmolality of $320 \mathrm{mOsm} /$ $\mathrm{kg} \mathrm{H}_{2} \mathrm{O}$. The pipette solution contained (in mM) $N$-methyl- $D$-glucamine chloride, 120; $\mathrm{Cs}_{4}$-BAPTA, 5; and $\mathrm{Mg}$-ATP, 5. The ATP regeneration system Tris-phosphocreatinine $(20 \mathrm{~mm})$ and creatine kinase $(20 \mathrm{LT} / \mathrm{ml})$ was added to the internal solution to minimize rundown of the $\mathrm{Ca}^{2+}$ currents (Forscher and Oxford, 1985; Byerly and Yazejian, 1986). The internal solution was adjusted to pII 7.2 with fresh $\mathrm{CsOH}$ and to an osmolality of $315 \mathrm{mOsm} / \mathrm{kg} \mathrm{H} \mathrm{H}_{2} \mathrm{O}$. The rate of rundown under these conditions was $<5 \%$ over a $30 \mathrm{~min}$ period (ffrench-Mullen and Rogawski, 1992).

Recordings were carried out using the whole-cell, patch-clamp technique as previously described (french-Mullen and Rogawski, 1992) Following seal formation and prior to entering the whole-cell mode, electrode capacitance was neutralized by using the capacitance compensation circuitry of the Axopatch ID (Axon Instruments, Foster City, CA). In the whole-cell mode, the Axopatch was further adjusted to correct for $80-85 \%$ of the scries resistance. Command potential sequences were delivered to the patch-clamp amplifier and data were simultaneously acquired under computer control. Evoked currents were filtered at $10 \mathrm{kHz}(-3 \mathrm{~dB}, 8$-pole low-pass Bessel filter; Frequency Devices, Ilaverhill, MA), digitally sampled at $500 \mu \mathrm{sec}$ per point ( 50 $\mu$ sec per point for tail current measurements), and stored on magnetic media in digital form for later analysis. Capacitative and leakage currents were digitally subtracted from all records, which was carried out on line by using pCLAMP 5.51 (Axon Instruments). Capacitative transients decayed with a time constant of $100 \mu \mathrm{sec}$. Neurosteroid delivery was via a rapid superfusion system consisting of a side-by-side array of six $200 \mu \mathrm{m}$ i.d. capillary tubes positioned approximately within $500 \mu \mathrm{m}$ of the cell under study. Drug solutions were applied by gravity feed, and flow was computer controlled via solenoid valves. Solution changes were accomplished within $300-500 \mathrm{msec}$. The recording chamber was continuously perfused $(1 \mathrm{ml} / \mathrm{min})$ with normal bath solution and only one cell per dish was used.

Data analysis. For the quantitation of inhibition, peak current values were used. Percentage inhibition was detcrmincd according to the for- 
A

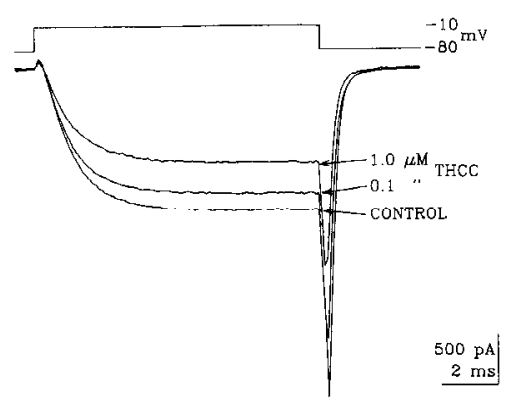

C

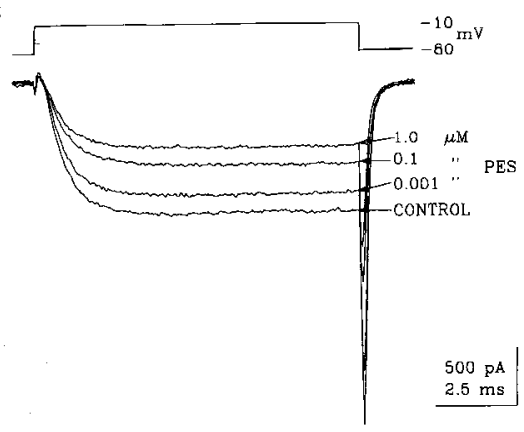

B

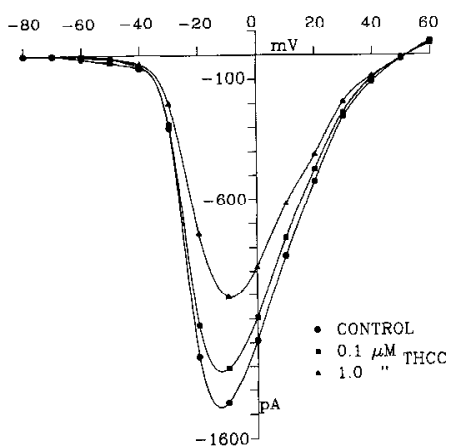

D

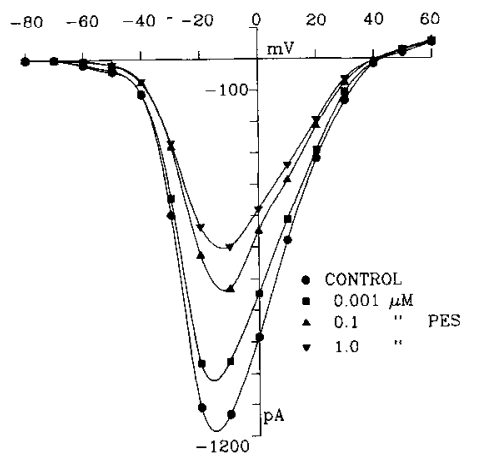

Figure 1. Neurosteroid (allotetrahydrocorticosterone, THCC; pregnenolone sulfate, $P E S$ ) inhibition of the whole-cell $\mathrm{Ca}^{2+}$ channel peak and tail currents. $\mathrm{Ca}^{2+}$ channel currents (using $3 \mathrm{mM} \mathrm{Ba}^{2+}$ as the charge carrier) were clicited by $10 \mathrm{msec}$ depolarizing voltage steps over the range of -80 to $+60 \mathrm{mV}$ in two different neurons. The individual (leak subtracted) step currents recorded at $-10 \mathrm{mV}$ are illustrated. $A$, THCC inhibition of the $\mathrm{Ca}^{2}$ : channel current at $-10 \mathrm{mV}$. B, Pcak Ca'+ current (measured $0.5 \mathrm{msec}$ prior to the end of the step) plotted as a function of membrane potential (current-voltage. $I-V)$ in the absence ( $)$ and presence of increasing concentrations of $(0.1(\square)$ and $1.0(\Delta) \mu \mathrm{M}$ THCC. I- $V$ values were obtained at steady-state values acquired with $200 \mathrm{msec}$ voltage steps in this and all subsequent traces. $C$, Concentration-dependent inhibition of the $\mathrm{Ca}^{2+}$ channel current by PES. $D, I-V$ relationship of the concentration-dependent inhibition; control $(\bullet), 0.001(\boldsymbol{\square})$ $0.1(\Delta)$, and $1.0(\nabla) \mu \mathrm{M}$ PES. The interval between successive steps in each family was $6 \mathrm{sec}$ mula $100 \times\left(1-I_{\text {trug }} / I_{\text {control }}\right)$, where $I_{\text {control }}$ is the leak-subtracted peak current amplitude prior to the drug application and $I_{\text {drug }}$ is the peak current amplitude in the presence of the test drug. During the drug applications, the $\mathrm{Ca}^{2+}$ current was repetitively evoked at intervals of 15 and $30 \mathrm{sec}$ for the 10- and 200-msec-duration depolarizing step protocols, respectively. Peak current gradually diminished as the drug application continued and there was no evidence of use-dependent block. Steady-state inhibition was typically achieved within $30-240 \mathrm{sec}$ after the onset of the drug superfusion. The $I_{\text {drug }}$ value used in the calculation of pereentage inhibition was obtained after being at a stcady-state valuc for $1 \mathrm{~min}$. Concentration-effect data were fitted with a nonlinear leastsquares program (NFIT, Island Products, Galveston, TX) according to the logistical equation $B=100 / 1+\left[\mathrm{IC}_{50} /(\mathrm{DRUG})\right]^{n t t}$, where [DRUG] is the drug concentration, $\mathrm{IC}_{5}$ is the concentration resulting in $50 \%$ inhibition, and $n H$ is an empirical parameter that describes the steepness of the curve and has the same meaning as the Hill coefficient. Tail current amplitudes were estimated by fitting the falling phase of the current to a single exponential [double exponential in the presence of $( \pm)$-BAY K 8644] and extrapolating the curve to zero time. Activation curves were determined by plotting tail current at $-80 \mathrm{mV}$ following activation of current by test pulses to different voltages and fit by the Boltzmann equation: $\left\{1+\exp \left[\left(V_{1 / 2}-V\right) / K\right]\right\}^{\cdots}$, where $V_{1 / 2}$ is the voltage for half-maximal activation, and $K$ is the slope factor. Fitting was done by NFIT (Island Products) and/or TABlecurve (Jandel Scientific, Corte Madera, CA). All traces are the average of three steps and leak subtracted except where noted; current-voltage $(I-V)$ data points at each potential are connected by a cubic spline. Final plotting was performed with sigmaplot (Jandel Scientific). All quantitative data are expressed as mean \pm SEM; $n$ indicates the number of cells examined Statistical analysis was performed using the paired or unpaired Student's $t$ test or the Mann-Whitney test. Results were considered significant only for $P<0.05$.

Chemicals. All reagents used in this study, except whcre noted, were obtained from Sigma (St. Louis, MO) and included the following:

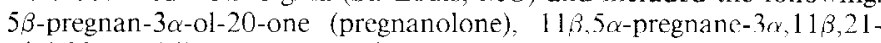
triol-20-one (allotetrahydrocorticosterone, THCC). $3 \alpha, 5 \alpha$-pregnane- $3 \alpha, 21$ diol-20-one (allotetrahydrodeoxycorticosterone, THDOC), 5-pregnen-3 $\beta$ ol-20-one (pregnenolone, PE), 5-pregnen- $3 \beta$ ol 20 -one-sulfate (pregnenolone sulfate. PES), 5-pregnen-3 $\beta$-ol-20-one-acetate (pregnenolone acetate), $5 \alpha$-pregnan- $3 \beta$-ol-20-one (allopregnanolone), nifedipine (NIF), PTX, $5 \alpha$-pregnan-3 $\beta$-ol-20-one acetate (allopregnanolune acelate), guanosine
S'-O-(2-thiodiphosphate) (GDP- $\beta$-S), and the 20 amino acid protein kinase inhibitor (rabbit sequence); PTX A-protomer (List Biological Labs, Inc., Campbell, CA); 1-(5-isoquinolinylsulfonyl)-2-methylpiperazine (H7), Rp-cyclic adenosine- $3^{\prime}, 5^{\prime}$-monophosphorothioate (Rp-cAMPS), Spcyclic adenosine $3^{\prime}, 5^{\prime}$-monophosphorothioate (Sp-cAMPS), and bisindolylmaleimide (BIS) or 3-[1-(3-dimethylaminopropyl)-indol-3-yl]-3-(indol-3-yl)-maleimide (Calbiochem, San Diego, CA); staurosporine (Fluka, Ronkonkoma, NY); PKCI 19-36 pseudosubstrate inhibitor (Sigma and Bachem Bioscience, Inc.. Philadelphia, PA), and $\omega$-conotoxin GVIA (CgTX Peninsula Laboratories. Bclmont, CA). Stock solutions $(10 \mathrm{~mm})$ of the steroids in ethanol were prepared daily; with steroid concentrations of $100 \mu \mathrm{M}$, final ethanol volume never exceeded $0.1 \%$ and the latter had no effect on the $\mathrm{Ca}^{2}$ current. Stock solutions $(10 \mathrm{~mm})$ of nifedipine and $\omega$-conotoxin were prepared weekly in ethanol and $\mathrm{H}_{2} \mathrm{O}$, respectively.

\section{Results}

The data presented in this report represent the results of wholecell recordings of $\mathrm{Ca}^{2}$ - channel current from more than 190 acutely dissociated adult guinea pig hippocampal CAl neurons. Macroscopic voltage-gated $\mathrm{Ca}^{2}+$ channel currents were recorded using $3 \mathrm{~mm} \mathrm{Ba}^{2+}$ as the external charge-carrying cation.

\section{Steroid inhibition of $\mathrm{Ca}^{2+}$ channel current}

Depolarizing voltage steps from $-80 \mathrm{mV}$ to various potentials positive to $-60 \mathrm{mV}$ elicited a high-threshold inward current that peaked rapidly and decayed gradually with maintained depolarizations (see Fig. 4). Superfusion with $50 \mu \mathrm{M}$ Cd $^{2-}$ virtually eliminated the inward current $(97 \pm 2 \%$ block, $n=5$; not shown), demonstrating that it is carricd by $\mathrm{Ca}$ ' channels. Peak current was reduced in a concentration-dependent manner by the neurosteroids. Current inhibition acquired steady-state values over the concentration range examined at $30-240 \mathrm{sec}$ with the fastest time to inhibition for the highest concentrations $(1-100 \mu \mathrm{M})$. We examined the time course of action of $0.001 \mu \mathrm{M}$ PE with $200 \mathrm{msec}$ depolarizing voltage steps at $30 \mathrm{sec}$ intervals. The time to achieve a steady-state inhibition ( $23 \pm 4 \%$ inhibition) 
Figure ?. Voltage dependence of the $\mathrm{Ca}^{2}$ ' channcl current inhibition by THCC and PES. Peak tail current amplitudes at $-80 \mathrm{mV}$ following test potentials from -80 to $+60 \mathrm{mV}$ were measured from the neurons in Figure 1. A, Tail current versus voltage before and during 0.1 and $1.0 \mu \mathrm{M}$ THCC. $B$, Percentage inhibition of the tail current amplitude versus test potential for THCC. $C$, Tail current versus voltage before and during 0.1 and $1 \mu \mathrm{M}$ PES. $D$, Percentage inhibition of tail current versus test potential for PES. Smooth curvés in $A$ and $C$ were fit to a Bollymann distribution; there was no change in the voltage dependence of activation for THCC and PES (see Materials and Methods for details). The $\mathrm{Ca}^{2+}$ channel current inhibition by THCC and PES was greater at the more negative test potentials.
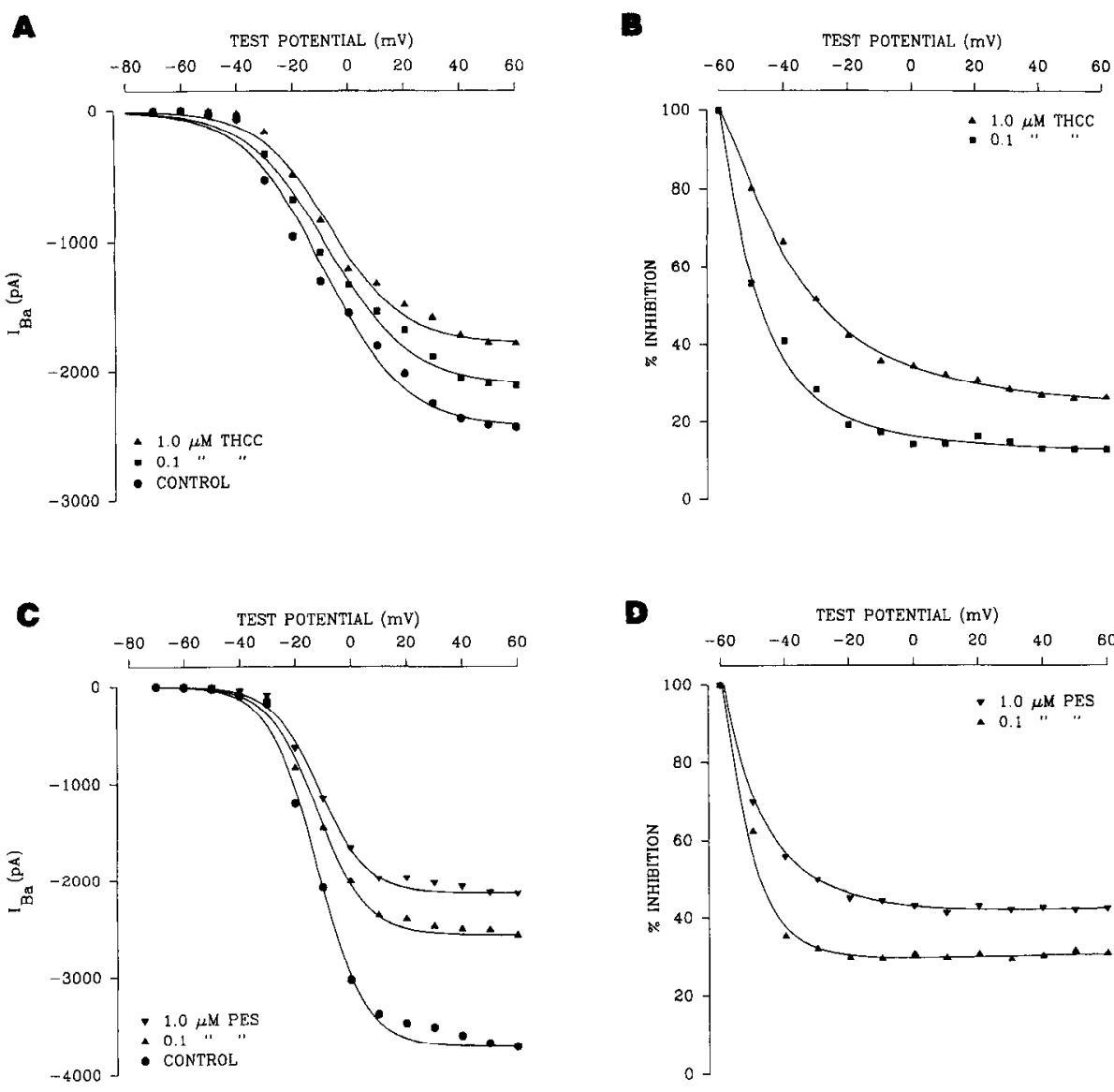

was $180 \pm 12 \mathrm{sec}$, with a recovery in wash to $95.6 \%$ of control in $270 \pm 15 \mathrm{sec}(n-3)$. The concentration-dependent inhibition for the neurosteroids THCC and PES is illustrated in Figure 1.

Brief ( $10 \mathrm{msec}$ ) depolarizing voltage steps were acquired over the range of -80 to $+60 \mathrm{mV}$ to examine the current-voltage $(I-V)$ relationship of the peak and tail currents, respectively. Between generation of the $I-V$ traces, $200 \mathrm{msec}$ depolarizing steps were acquired to assess control and steady-state drug values; thus, $I-V$ values were generated at steady-state values. Figure $1 A$ illustrates the $\mathrm{Ca}^{2+}$ channel current recorded at $-10 \mathrm{mV}$ in the presence of various concentrations of THCC. For this neuron, the peak current (measured $0.5 \mathrm{msec}$ prior to the end of the step) was depressed $13 \%$ and $34 \%$ by 0.1 and $1 \mu \mathrm{m}$, respectively. Tail current amplitude, measured at $-80 \mathrm{mV}$ following a step to $-10 \mathrm{mV}$, was also depressed. Increasing concentrations of $1 \mathrm{HCC}$ on the same cell gave a concentrationdependent inhibition of peak current amplitude (Fig. 1B). PES also inhibited the $\mathrm{Ca}^{2-}$ current in a concentration-dependent manner, as illustrated in Figure $I C$. In this cell, peak $\mathrm{Ca}^{2+}$ channel current was suppressed $12 \%, 36 \%$, and $54 \%$ for 0.001 , 0.1 , and $1 \mu \mathrm{M}$ PES. Similar to THCC, PES also induced a concentration-dependent inhibition of the peak $\mathrm{Ca}^{2+}$ channel current amplitude (Fig. 1D). However, substitution of an acetate, pregnenolone acetate $(10 \mu \mathrm{M})$, for the sulfate moicty had no effect on the $\mathrm{Ca}^{2}$ chanmels $(n-3)$. Pregnanolone $(n-3)$ and THDOC $(n=3)$ also depressed the $\mathrm{Ca}^{2-}$ current (range of 10 nM to $50 \mu \mathbf{M}$; not shown)

We evaluated the possible use dependence of the inhibition in experiments where the $\mathrm{Ca}^{2}$ channel current was repetitively activated with $5-10$-msec-duration voltage steps at stimulus intervals of $1,5,10$, and 40 sec applied following an equilibrium period of $2 \mathrm{~min}$ as previously described (ffrench-Mullen and Rogawski, 1992). We failed to observe any progressive development of block during the stimulus train for THCC. PES, and $\mathrm{PE}$ ( $n=6$; not shown).

In an attempt to distinguish between an external membrane receptor protein and/or a channel protein site versus an intracellular site of action. we internally dialyzed neurons with 0.1 $\mu \mathrm{M}$ PES added to the intracellular solution. Following the runup of the $\mathrm{Ca}^{2+}$ channel current, comparison of PES-dialyzed neurons $(n=4)$ with randomly selected neurons $(n=4)$ showed no significant difference in the peak $\mathrm{Ca}^{2}$ channel currents $(P>$ $0.2 ; 1732 \pm 293 \mathrm{pA}$ and $1653 \pm 189 \mathrm{pA}$ for normal and PES dialyzed, respectively). Concomitant extracellular application of PES to PES-dialyzed neurons showed no significant difference in depressing the peak $\mathrm{Ca}^{2-}$ channel current: control, $12 \pm 4 \%$, $17 \pm 4 \%, 31 \pm 3 \%, 46 \pm 5 \%$, and $54 \pm 4 \%$, compared to internal PES, $8 \pm 1 \%, 17 \pm 2 \%, 24 \pm 1 \%, 41 \pm 3 \%$, and $46 \pm$ $2 \%$ with $0.0001,0.001,0.01,1$, and $10 \mu \mathrm{M}$ PES, respectively ( $P$ $>0.2 ; n=6$ each). Together, these data suggest, but do not conclusively prove, that PES interacts with its binding site from the external surface. A similar finding was reported by Lambert et al. (1991), where intracellular dialysis of pregnanolone or the steroid anesthetic alphaxalone did not activate or inhibit the potentiation of the GABA receptor-mediated currents, suggesting an extracellular site of action.

The elimination of $\mathrm{GABA}_{\mathrm{A}}$ receptor involvement with the steroid inhibition of $\mathrm{Ca}^{2}+$ channel currents was previously reported, in that perfusion with $10 \mu \mathrm{M}$ picrotoxin had no effect on the $\mathrm{Ca}^{2}$ channel current and did not prevent the inhibitory 

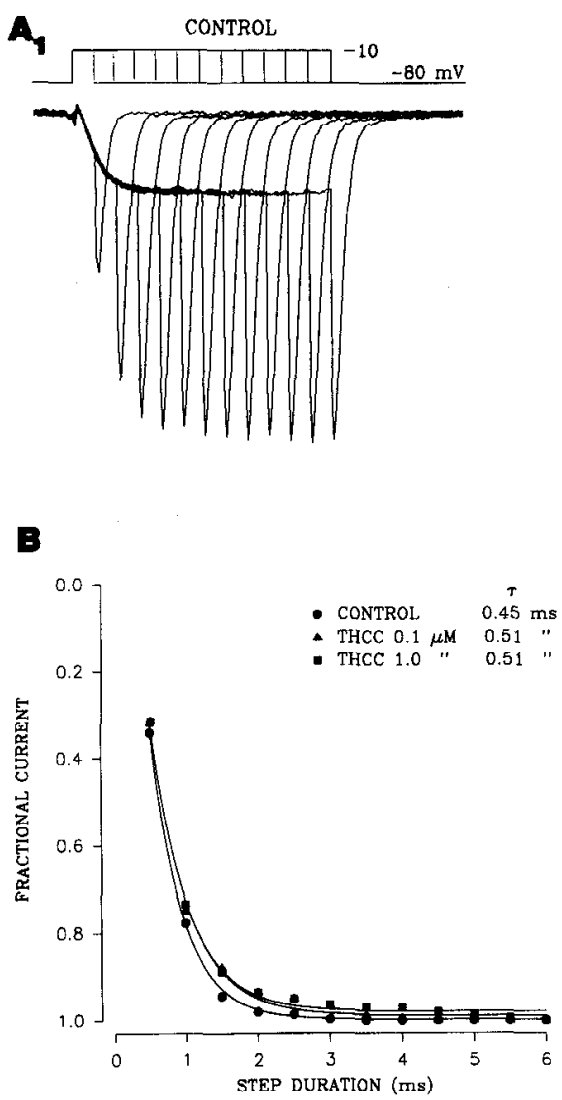

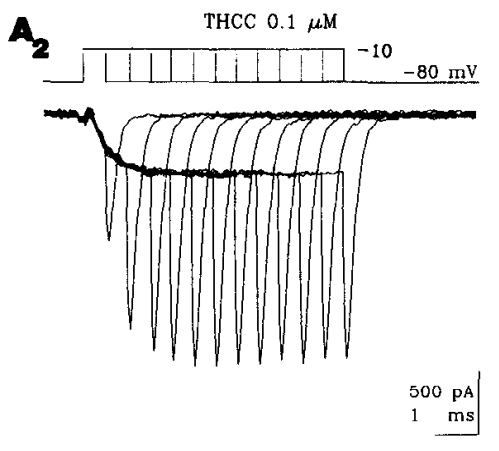

C

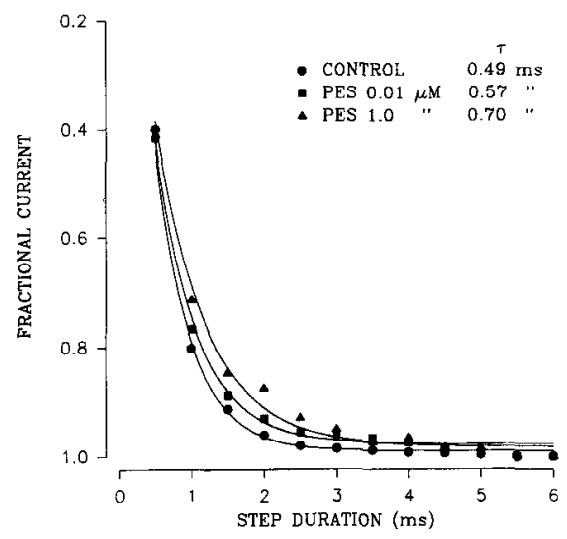

Figure 3. Rate of $\mathrm{Ca}^{2+}$ channel current activation is slowed by allotetrahydrocorticosterone $(T H C C)$ and pregnenolone sulfate (PES). $A, \mathrm{Ca}^{2+}$ channel currents and their tail currents evoked by depolarizing steps of various duration (0.5-6 msec, $0.5 \mathrm{msec}$ increments) in the absence $\left(A_{l}\right)$ and presence of 0.1 $\mu \mathrm{M}$ THCC $\left(A_{2}\right)$. The interval between successive steps was $1 \mathrm{sec}$. $\Lambda \mathrm{fter}$ equilibration of the preparation with THCC but before the acquisition of the traces shown in $A_{2}$, steady-state inhibition was achieved with several $200 \mathrm{msec}$ pulses. For the graphs in $B$ and $C$, extrapolated tail current amplitudes (at $-80 \mathrm{mV}$ ) were normalized to the maximum tail current amplitude ( $6 \mathrm{msec}$ step); the continuous curves are the best singleexponential fits to the control and steroid data. $B$, THCC. $C$, PFS. action of THCC, PE, and PES (ffrench-Mullen and Spence, 1991; Spence et al., 1991). In the present study, this was further confirmed with six additional neurons (not shown).

The concentration-effect relationships for the steady-state inhibition of the peak $\mathrm{Ca}^{2+}$ channel current by the neurosteroids was examined with $200 \mathrm{msec}$ voltage steps to $-10 \mathrm{mV}$ from a holding potential of $-80 \mathrm{mV}$. PE and its sulfate ester, PES, had a maximal inhibition ( $64 \pm 3 \%$ and $57 \pm 4 \%$, respectively) at $100 \mu \mathrm{M}$ (control; see Fig. 8A,B). The $\mathrm{IC}_{50}$ values were 11 and 130 nM for PES and PE, respectively, with an $n H$ of 0.3 for both compounds. THCC also gave a sigmoidal dose-effect curve with an $\mathrm{IC}_{50}=298 \mathrm{nM}$ and an $n H$ of 0.7 , suggesting a single binding site (control; see Fig. 8C). However, PES, PE, and THCC gave a maximal inhibition of the $\mathrm{Ca}^{2+}$ channel current at saturating concentrations that only inhibited a fraction of the total $\mathrm{Ca}^{2+}$ channel current. In addition, at these maximum concentrations, there was essentially no reversibility of the inhibition of the $\mathrm{Ca}^{2+}$ channel current with wash, further suggesting that maximal inhibition had occurred. Allopregnanolone also inhibited the $\mathrm{Ca}^{2+}$ channel current in a concentration-dependent manner with a maximal $37 \pm 4 \%$ inhibition at $10 \mu \mathrm{M}$ with some reversibility ( $64 \pm 3 \%$ of control with wash; $n=5$; not shown). Interestingly, allopregnanolone acetate $(10 \mu \mathrm{M})$ had no effect on the $\mathrm{Ca}^{2+}$ channel current $(n=3)$. Progesterone, which is synthesized in brain from $\mathrm{PE}$, had no effect on the $\mathrm{Ca}^{2+}$ channel current at $100 \mu \mathrm{M}$ (4\% inhibition, $n=9$; not shown).

\section{Activation and deactivation kinetics}

We investigated the effect of THCC and PES on the voltage dependence of activation of the $\mathrm{Ca}^{2+}$ channel conductance. The smooth curves to the peak tail current amplitudes from Figure 1, $A$ and $C$, were fit according to a Boltzmann distribution (see Materials and Methods). There was a minimal depolarizing shift by THCC in this cell, where the voltage at which half the channels are open $\left(V_{1 / 2}\right)$ was $-8.5,-7$, and $-7 \mathrm{mV}$, and slope amplitude ( $k$ ) was $14.4,14.6$, and $14.6 \mathrm{mV}$ for control, 0.1 , and $1.0 \mu \mathrm{M}$ THCC, respectively (Fig. 2A). For the cell with PES in Figure $2 C$, the $V_{1 / 2}$ was $-12,-11.9$, and $-11.4 \mathrm{mV}$ and $k$ was $8.5,8.7$, and $8.6 \mathrm{mV}$ for control and 0.1 and $1.0 \mu \mathrm{M}$ PES, respectively. The voltage dependence of activation of the $\mathrm{Ca}^{2+}$ channel current was essentially unchanged by both THCC and PES.

The $I-V$ relationships for THCC and PES (Fig. 1) suggested that the inhibition of the $\mathrm{Ca}^{2+}$ channel current was voltage dependent. The percentage inhibition of the peak tail current amplitudes from Figure 2, $A$ and $C$, was plotted versus test potential for THCC and PES. As illustrated in Figure 2, $B$ and $D$, both THCC and PES, respectively, inhibited the $\mathrm{Ca}^{2+}$ channel current in a voltage-dependent manner, with the greatest amount of inhibition occurring at the more negative test potentials.

To determine whether THCC and/or PES had an effect on the time course of deactivation of the $\mathrm{Ca}^{2+}$ channel current, we examined the tail currents generated at $-80 \mathrm{mV}$ following a depolarization to $-10 \mathrm{mV}$ (not shown). THCC $(n=3)$ significantly slowed the time course of deactivation $(P<0.03$ from control): $\tau=182 \pm 5,213 \pm 8,215 \pm 7$, and $216 \pm 8 \mu \mathrm{sec}$ for control, $0.01,0.1$, and $1 \mu \mathrm{M}$ THCC, respectively. Similarly, PES $(n=3)$ also significantly slowed $(P<0.05$ from control) the time course: $\tau=192 \pm 3,223 \pm 4,230 \pm 5$, and $223 \pm 5 \mu \mathrm{sec}$ for control, $0.01,0.1$, and $1 \mu \mathrm{M}$ PES, respectively. We also 

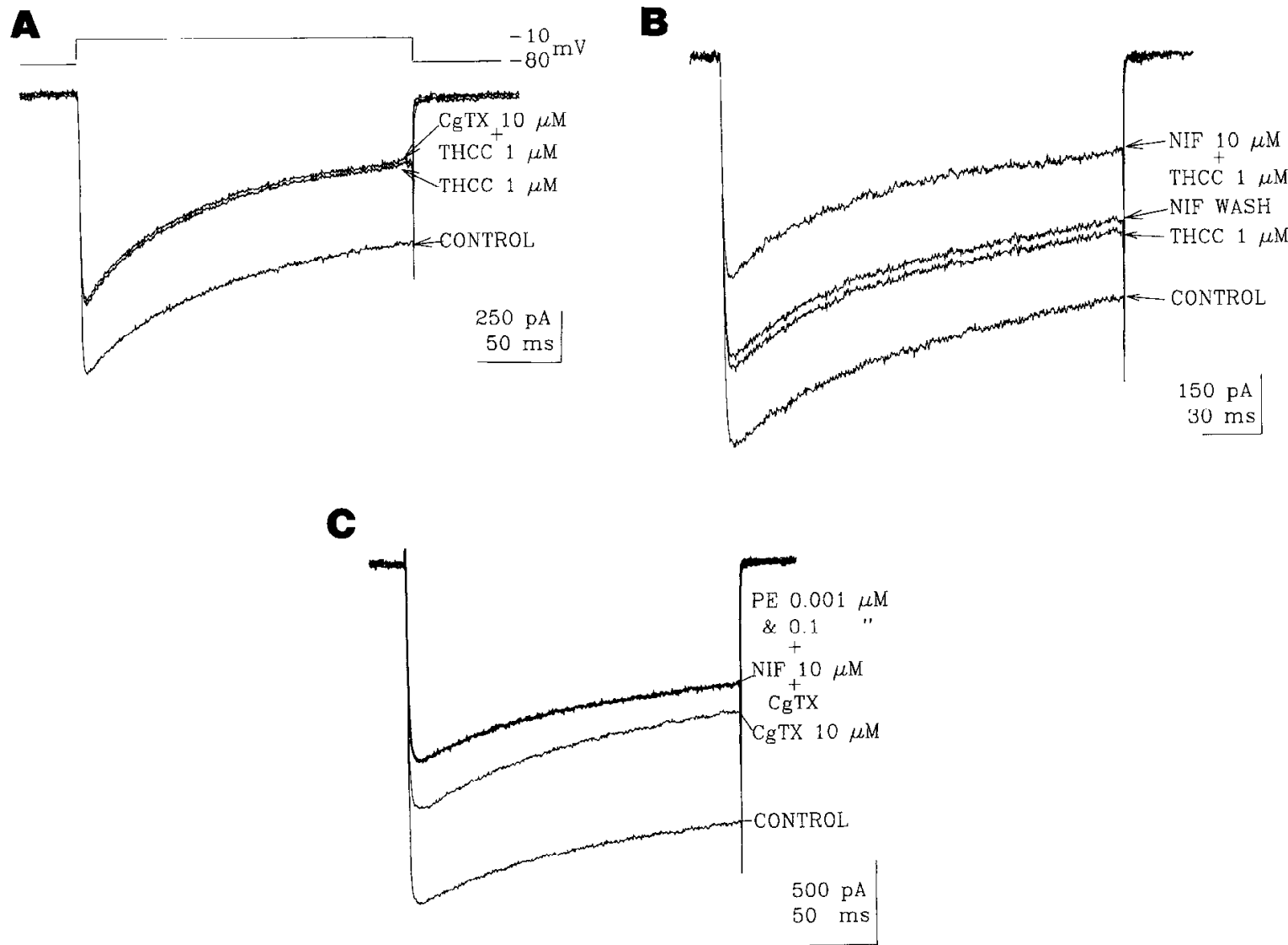

Figure 4. Neurosteroid effects in the presence of the $\mathrm{Ca}^{2+}$ channel inhibitors $\omega$-conotoxin $(\mathrm{CgTX})$ and nifedipine (NIF). Currents were evoked by a $200 \mathrm{msec}$ voltage step to $-10 \mathrm{mV}$ from a holding potential of $-80 \mathrm{mV}$ in different neurons. $A$, THCC depressed the Ca ${ }^{2}$ chramel current ( $26 \%$ inhibition peak current); application of CgTX in the continued presence of THCC had a minimal effect ( $1 \%$ ). B, Following the THCC inhibition $(21 \%)$ of the $\mathrm{Ca}^{2+}$ channel current, application of NIF inhibits the L-type current in the presence of THCC. Following inhibition of the Ca ${ }^{2+}$ channel current by NIF, perfusion with only THCC reversed the NIF inhibition of the L-type $\mathrm{Ca}^{2+}$ current. $C$, Perfusion with $\mathrm{Cg}$ IX depresses a fraction (28\%) of the $\mathrm{Ca}^{2+}$ channel current (N-type); subsequent perfusion of NIF with CgTX inhibited the (L-type current). The remaining current is the CgTX/NIF-insensitive current. Perfusion of PE $(0.001$ and $0.1 \mu \mathrm{M})$ in the presence of CgTX and NIF had no effect.

examined whether the slowing of the time constant was voltage dependent or uniform across a range of potentials. The deactivation of the $\mathrm{Ca}^{2+}$ channel current is voltage dependent, with the speed of deactivation increasing as the repolarization level is brought to more negative potentials (ffrench-Mullen and Rogawski, 1992). Perfusion with THCC, PES, and PE slowed the time constants uniformly over the voltage range of -30 to 50 $\mathrm{mV}(n=2$ each).

We had previously observed that PE and PES slowed the time to peak of the $\mathrm{Ca}^{2+}$ channel current generated by $200 \mathrm{msec}$ depolarizing steps in these CAl neurons (Spence et al., 1991). Qualitative observations of other steroids in this study also suggested a similar mechanism of action. We therefore investigated the effect of THCC and PES on the time course of activation of the $\mathrm{Ca}^{2+}$ channel current using the extrapolated tail current amplitudes (at $-80 \mathrm{mV}$ ) as an estimate of the instantaneous conductance at the end of the depolarizing step (ffrenchMullen and Rogawski, 1992).

Figure $3 A$, illustrates a family of $\mathrm{Ca}^{2+}$ channel currents and their tail currents evoked by depolarizing steps of increasing duration from 0.5 to $6 \mathrm{msec}$ in $0.5 \mathrm{msec}$ increments. The $\mathrm{Ca}^{2+}$ channel currents and tail currents were reduced in amplitude by $0.1 \mu \mathrm{M}$ (Fig. $3 A_{2}$ ) and $1 \mu \mathrm{M}$ (not shown) THCC. However, as shown in Figure $3 B$, the rate of activation of the $\mathrm{Ca}^{2+}$ con- ductance as determined from the steady-state tail currents was slowed by THCC ( $\tau=0.45,0.51,0.51 \mathrm{msec}$ for control and 0.1 and $1 \mu \mathrm{M}$ THCC, respectively). Overall, THCC $(n=3)$ significantly slowed the rate of activation $(P<0.04$ from control, paired $t$ test): $\tau-0.41 \pm 0.02,0.48 \pm 0.02$, and $0.52 \pm 0.01$ msec for control and 0.1 and $1 \mu \mathrm{M}$ THCC, respectively. PES also slowed the rate of activation as shown in Figure $3 C$. Similar to THCC, PES $(n=4)$ significantly slowed the rate of activation $(P<0.04$ from control; paired $t$ test $): \tau=0.48 \pm 0.02,0.54 \pm$ 0.02 , and $0.69 \pm 0.02 \mathrm{msec}$ for control and 0.01 and $1 \mu \mathrm{M}$, respectively. The differences in the rate of activation between control and drug at $1 \mu \mathrm{M}$ were $27 \%$ and $43 \%$ for THCC and PES, respectively.

\section{Neurosteroids and $\mathrm{Ca}^{2+}$ channel subtypes}

Hippocampal neurons have multiple types of $\mathrm{HVA} \mathrm{Ca}^{2+}$ channels that at the whole-cell level can be pharmacologically classified into various subtypes, including the $\mathrm{T}$-, N-, L-, and P-current (Mogul and Fox, 1991; O'Dell and Alger, 1991; Regan et al., 1991; Mintz et al., 1992). The low-threshold or T-type current is not present in the adult guinea pig CAl cells (Doerner and Alger, 1988; Thompson and Wong, 1991). Similar to guinea pig CA3 (Mogul and Fox, 1991) and rat hippocampal CA1 neurons (Regan et al., 1991; Mintz, et al., 1992), the high-thresh- 

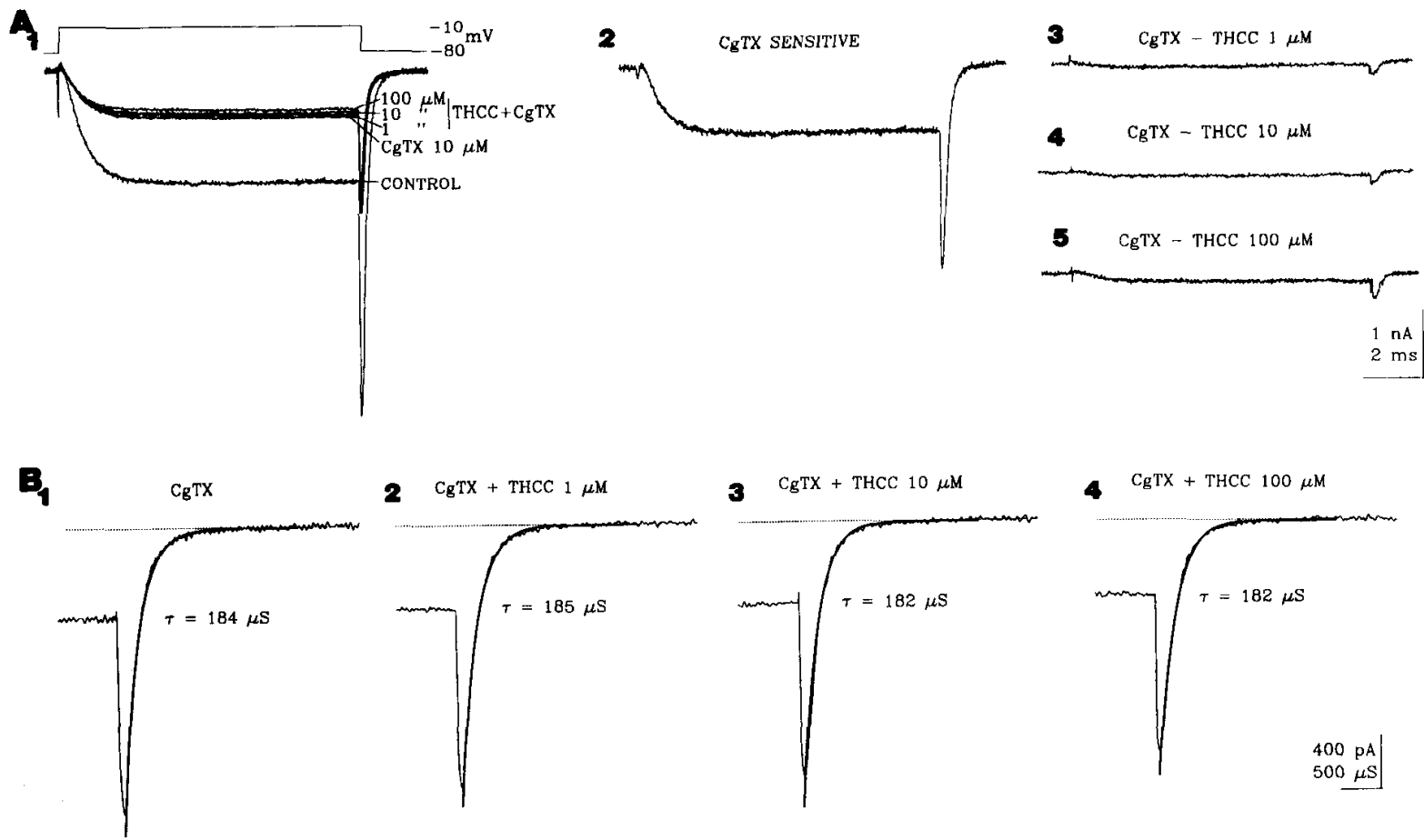

Figure 5. Residual inhibition of the $\mathrm{Ca}^{2+}$ channel current by allotetrahydrocorticosterone (THCC) following inhibition of the $\mathrm{N}$-type by $\omega$-conotoxin $(C g I X)$. Ca ${ }^{2+}$ channel current was evoked with a $10 \mathrm{msec}$ voltage step from a holding potential of $-80 \mathrm{mV}$ to a test potential of $-10 \mathrm{mV}$. 1 ail currents, measured at $-80 \mathrm{mV}$, were best fit to a single exponential. $A_{l}$, Peak and tail currents in the presence of CgTX and 1,10 , and $100 \mu \mathrm{M}$ THCC. CgTX gave a $57 \%$ inhibition of the $\mathrm{Ca}^{2+}$ channel current; 10 and $100 \mu \mathrm{M}$ THCC showed a minimal additional inhibition. $A_{2}$, Difference current of the current remaining in $\mathrm{CgTX}$ from control illustrating the $\mathrm{Ca}^{2+}$ current (N-type) sensitive to $\mathrm{CgTX}$ that had a peak amplitude of 923 pA. $A_{5}-A_{s}$, Difference currents of the records in $A_{l}$, illustrating the minimal effect of $1-100 \mu \mathrm{M}$ THCC on the peak and tail currents. $B_{l}$, Tail current of the CgTX-sensitive current with a decay time constant $(\tau)$ of $184 \mu \mathrm{sec}$ (from the same neuron as in $A$ ). $B_{2}$, Tail current in CgTX and $1 \mu \mathrm{M}$ THCC. $B_{s}$, In $10 \mu \mathrm{M}$ THCC. $B_{4}$, In $100 \mu \mathrm{M}$ THCC. While there was a small decrease in tail current amplitude, $8 \%, 11 \%$, and $19 \%$ inhibition from the tail current with CgTX alone, there was no change in the decay time constant. Dotted line indicates the baseline current prior to depolarization; fitted solid line is superimposed on raw data.

old current in guinea pig CA1 neurons can be pharmacologically divided into CgTX-sensitive (N-type) and the dihydropyridine NIF-sensitive (L-type) currents, respectively, and a P-type current that is insensitive or resistant to CgTX and NIF (Fig. 4C). Similar to other hippocampal neurons (Mogul and Fox, 1991 ; Regan et al., 1991), guinea pig CA1 neurons possess quite a large component of the high-threshold current $(\approx 40 \%)$ that is typically inhibited by the dihydropyridine NIF (Figs. $4 B ; 6 B$, hatched bars) and a fraction inhibited by CgTX (Figs. 4C, $5 A$, $6 A)$. The dihydropyridine agonist ( \pm )-BAY K $8644(0.1-1 \mu \mathrm{M})$ increased the peak inward $\mathrm{Ca}^{2+}$ current at test potentials of -50 to $10 \mathrm{mV}$, shifted the $I-V$ relationship in the hyperpolarizing direction that was inhibited by $10 \mu \mathrm{M} \operatorname{NIF}(n=5$; not shown). CgTX produced a maximal inhibition $(32 \pm 3 \%)$ of a fraction of the $\mathrm{Ca}^{2+}$ channel current at concentrations $\geq 1 \mu \mathrm{M}$ (with no shift in the $I-V$ relationship; $n=6$ ) with an $\mathrm{IC}_{50}$ of $48 \mathrm{nM}$ and an $n H$ of 0.7 (not shown). For this study, the resistant $\mathrm{Ca}^{2+}$ channel current reflects that $\mathrm{CgTX} / \mathrm{NIF}$-insensitive current.

We had previously observed that in the presence of CgTX, THCC had no inhibitory effect on the $\mathrm{Ca}^{2+}$ channel current (ffrench-Mullen and Spence, 1991); we therefore examined whether THCC inhibited the same fraction of current as did CgTX. In Figure $4 A, 1 \mu \mathrm{M}$ THCC inhibited the peak $\mathrm{Ca}^{2+}$ channel current by $26 \%$. Perfusion of $10 \mu \mathrm{M} \mathrm{CgTX}$ with $1 \mu \mathrm{M} \mathrm{THCC}$ essentially demonstrated no effect $(1 \%)$ by $\mathrm{CgTX}$, suggesting that THCC had occluded the inhibitory effect of $\mathrm{Cg} T X$. However, if THCC and CgTX inhibited the same fraction of current, the N-type, then NIF would inhibit the L-type in the presence of THCC. This is illustrated in Figure $4 B$, where having inhibited a fraction of the $\mathrm{Ca}^{2+}$ channel current with $1 \mu \mathrm{M}$ THCC (21\%) subsequent perfusion with $10 \mu \mathrm{M}$ NIF in the presence of THCC gave an additional (30\%) inhibition of the L-type $\mathrm{Ca}^{2+}$ channel current. Perfusion of THCC alone reversed the inhibitory effect of NIF (Fig. $4 B$, NIF wash). Final wash with control solution, reversed the peak $\mathrm{Ca}^{2+}$ channel current to $80 \%$ of control (not shown). The same protocol yielded the same results in two other neurons; the reverse protocol, application of NIF then THCC, also demonstrated further inhibition by THCC ( $n$ $=3$; not shown).

To determine further whether $\mathrm{CgTX}$ and THCC modulated the same fraction of $\mathrm{Ca}^{2+}$ channel current, we examined the difference and tail currents in the presence of $\mathrm{CgTX}$ and THCC. This is illustrated in Figure $5 A_{l}$, where following the application of $10 \mu \mathrm{M} \mathrm{CgTX} \mathrm{(43 \%} \mathrm{inhibition),} \mathrm{subsequent} \mathrm{perfusion} \mathrm{of} \mathrm{THCC}$ (1-100 $\mu \mathrm{M})$ plus CgTX showed no or minimal inhibition of the remaining current, best illustrated by examining the difference currents.

The difference currents for this particular neuron illustrate the current sensitive to inhibition (Fig. $5 A_{t}-A_{5}$ ). The peak CgTXsensitive current had an amplitude of $923 \mathrm{pA}$ (Fig. $5 A_{2}$ ) and the decay of the tail current had a time constant $(\tau)=184 \mu \mathrm{sec}$ and an amplitude of $2100 \mathrm{pA}$ (Fig. $5 B_{l}$ ). The difference current for $1 \mu \mathrm{M}$ THCC demonstrated that this concentration had no effect on the peak current (Fig. $5 A_{3}$ ) and a very small effect on the tail 
Figure 6. Pregnenolone $(P E)$ inhibits both the $\omega$-conotoxin-GVIA ( $C g T X)$ and nifedipine $(N I F)$-sensitive $\mathrm{Ca}^{2+}$ channel currents. Data were taken from the peak current evoked by $200 \mathrm{msec}$ voltage steps from a holding potential of $-80 \mathrm{mV}$ to a test potential of -10 $\mathrm{mV} . A$, In the presence of $10 \mu \mathrm{M} \mathrm{CgTX}$ (inhibition of the $\mathrm{N}$-type $\mathrm{Ca}^{2+}$ channel current; hatched bars), PE inhibits an additional fraction but not all the remaining current (open bars). $B$, In the presence of $10 \mu \mathrm{m}$ NIF (inhibition of the L-type $\mathrm{Ca}^{2+}$ channel current; hatched bars), PE continues to inhibit a substantial, but not all of the remaining current (open bars). Number of cells examined is given in each column.

\section{A}

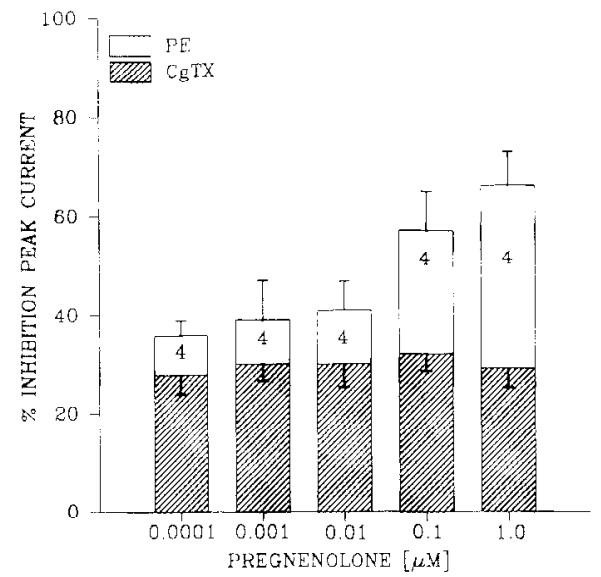

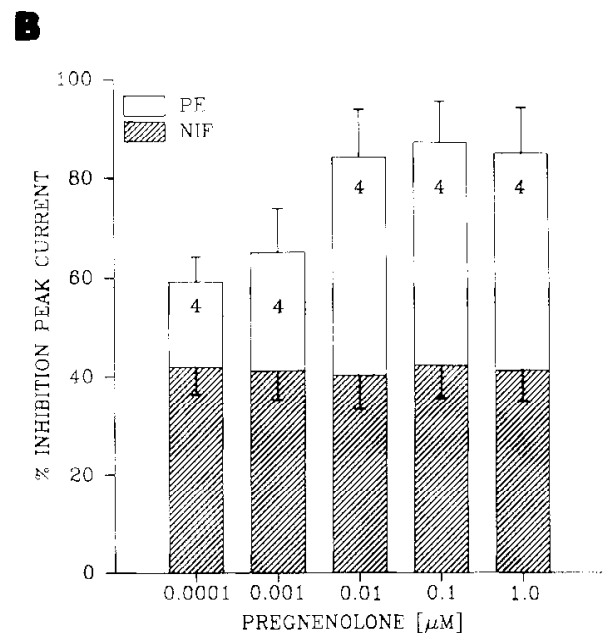

current, $1933 \mathrm{pA}$ versus $2100 \mathrm{pA}$ in the presence of $\mathrm{CgTX}$ (Fig. $5 B_{2}$ ). At $10 \mu \mathrm{M}$, THCC gave a small additional inhibition, as indicated by the difference current (amplitude of 27 pA; Fig. $5 A_{4}$ ) and a small reduction in the tail current amplitude by 233 pA (Fig. 5B ). At $100 \mu \mathrm{M}$ THCC, there was an additional inhibition where the difference current had an amplitude $90 \mathrm{pA}$ (Fig. $5 A_{5}$ ); the tail current amplitude decreased by $400 \mathrm{pA}$ (Fig. $\left.5 B_{4}\right)$. The deactivation kinetics of the tail currents during perfusion with the increasing concentrations of THCC showed no difference when treated with $\mathrm{CgTX}$ alone (Fig. $5 B_{1}-B_{4}$ ). The experiments in Figures 4 and 5 suggested that while CgTX for the most part occluded the THCC inhibition, the higher concentrations of THCC (10 and $100 \mu \mathrm{M})$ demonstrated a small, partial inhibition of the L-type current. THCC had no effect on the CgTX/NIF-insensitive current ( $n=7$; not shown).

PE $(0.001-1 \mu \mathrm{M})$ had no effect on the CgTX/NIF-insensitive current $(n=5$; Fig. $4 C$ ). In contrast to this lack of effect by $\mathrm{PE}$, in the presence of either $10 \mu \mathrm{M}$ CgTX or $10 \mu \mathrm{M}$ NIF, PE continued to inhibit a fraction of the remaining current, as illustrated in Figure 6. In Figure 6A, the hatched bars represent the inhibition by $10 \mu \mathrm{M} \mathrm{CgTX}$. Increasing concentrations of $\mathrm{PE}$ (open bars) in the presence of $\mathrm{CglX}$ inhibited the $\mathrm{Ca}^{2+}$ channel current. Increasing concentrations of PE (open bars) $(n=4)$ also inhibited the $\mathrm{Ca}^{\text {?+ }}$ channel current in the presence of $10 \mu \mathrm{M}$ NIF (hatched bars) (Fig. 6B). These results suggested that PE was nonselective in that it could inhibit either the $\mathrm{N}$ - and L-type currents, but not the resistant current.

We also observed that another neurosteroid, allopregnanolone, had no inhibitory effect in the presence of $10 \mu \mathrm{M} \mathrm{CgTX}$ ( $2 \pm 2 \%$ inhibition at $1 \mu \mathrm{M} ; n=3$ ), but inhibited a fraction of the $\mathrm{Ca}^{2+}$ channel current in the presence of $10 \mu \mathrm{M} \mathrm{NIF}(n=3$; $18 \pm 2 \%, 23 \pm 4 \%, 25 \pm 7 \%$, and $33 \pm 8 \%$ at $0.00001,0.0001$ 0.01 , and $1 \mu \mathrm{M}$ ) with a maximal inhibition equal to that of $\mathrm{CgTX}$ $(32 \pm 3 \%)$ and no effect on the resistant current $(n=3$; not shown). These results suggested that this steroid, like THCC, appeared primarily to inhibit the $\mathrm{N}$ - but not the L-type current.

\section{$G$-protein mediation of neurosteroid inhibition}

We tested for the involvement of $\mathrm{G}$-proteins in the neurosteroid inhibition of the $\mathrm{Ca}^{2}$ : channel current by examining neurons that had been incubated with PTX. Of the G-proteins expressed in neurons, some are sensitive to PTX (such as G $\alpha_{j}$ and $\mathrm{G} \alpha_{0}$ ), which prevents their interaction by catalyzing their ADP ribosylation (Gilman, 1987). Animals were pretreated for $48 \mathrm{hr}$ with PTX at $1000 \mathrm{ng} / 24 \mathrm{hr}$; following this, neurons were then acutely isolated from the CAl region. The characteristics of neurons isolated from the PTX-treated animals were the same as normal animals for there was no significant difference in peak current amplitudes $(P>0.5)$. For example, following the normal runup of the $\mathrm{Ca}^{2+}$ channcl current, the peak current from randomly selected neurons from untreated animals was $1423 \pm 99$ pA ( $n=15)$ compared with the peak current from PTX-treated animals, $1409 \pm 93 \mathrm{pA}(n=15)$.

An example of the effect of PTX on the PES inhibition of the $\mathrm{Ca}^{2+}$ channel current is illustrated in Figure $7 \mathrm{~A}$, where the peak current inhibition at $10 \mu \mathrm{M}$ was $10 \%$ compared to $54 \%$ (see Fig. $8 A$, control). PTX significantly diminished the effect of PES at all concentrations $(P<0.02 ;$ maximum $13.8 \%$ inhibition at 10 $\mu \mathrm{M})$ (Fig. 8. ). Inhibition of the $\mathrm{Ca}^{2+}$ channel current by THCC was also significantly diminished $(P<0.02$; maximum $13 \%$ inhibition at $10 \mu \mathrm{M})$ (Fig. $8 \mathrm{C}$ ). Inhibition by PE was also significantly diminished $(P<0.03)$ in PTX-treated neurons (maximum $22 \%$ inhibition at $10 \mu \mathrm{M}$ ) (Fig. $8 B$ ).

To confirm PTX's effects on the neurosteroids in these cells, we compared the effect NIF on the $\mathrm{Ca}^{2+}$ channel current in untreated and PTX-treated neurons. NIF is an L-type $\mathrm{Ca}^{2}$. channel blocker but at higher concentrations $(\geq 10 \mu \mathrm{M})$ also inhibits voltage-dependent sodium and potassium channels (Jones and Jacobs, 1990) and therefore should be unaffected by PTX. In the untreated neurons, inhibition of the L-type $\mathrm{Ca}^{2+}$ channel current was $14 \pm 3 \%, 26 \pm 4 \%$, and $42 \pm 3 \%$ for 0.01 , 1 , and $10 \mu \mathrm{M} \mathrm{NIF}$, respectively $(n=5)$. In PTX-treated neurons, there was no significant difference obscrved $(P>0.2)$, where the current inhibition was $15 \pm 1 \%, 24 \pm 1 \%$, and $38 \pm 1 \%$ for $0.01,1$, and $10 \mu \mathrm{M} \mathrm{NIF}$, respectively $(n=5)$.

We also included the A-protomer of PTX in the patch pipette at a concentration of $2 \mu \mathrm{g} / \mathrm{ml}$; the cells were dialyzed for $15-50$ min before drug application. The responses to PES and THCC were significantly diminished by the A-protomer, as illustrated for PES in Figure $7 B$, where al $10 \mu \mathrm{M}$ PES showed a $11 \%$ inhibition of the peak current. For PES $(n=6)$, the percentage inhibition was $3 \pm 3 \%, 4 \pm 2 \%, 5 \pm 1 \%, 13 \pm 4 \%$, and $26 \pm$ $5 \%$ for $0.001,0.01,0.1,1$, and $10 \mu \mathrm{M}$, and was significantly different from control $(P<0.01$ for all concentrations). A similar 


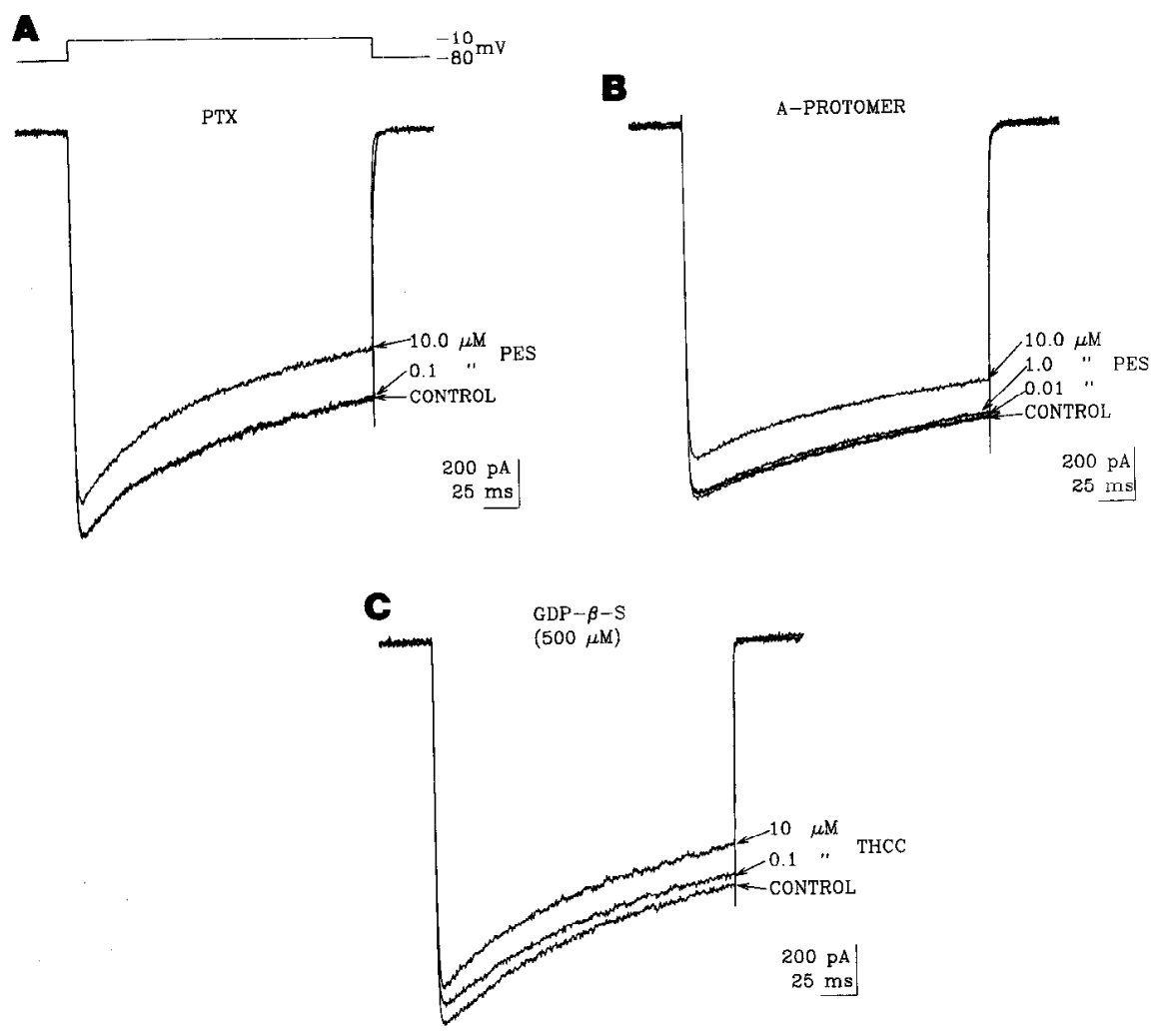

Figure 7. Diminution of the neurosteroid $\mathrm{Ca}^{2+}$ channel current inhibition by modulators of G-proteins. $A$, Pertussis toxin $(P T X)$ greatly diminished the pregnenolone sulfate $(P E S)$ inhibition of the peak $\mathrm{Ca}^{2+}$ channel current $(8 \%$ inhibition). Neurons were acutely isolated from PTX-treated animals; see Materials and Methods for details. $B$, Internal dialysis of the A-protomer of PTX (50 min for this cell) also greatly reduced the PES inhibition $(10 \%$ inhibition peak current). $C$, Internally dialyzed GTP- $\beta$-S also greatly reduced the amount of inhibition by THCC ( 5 and $10 \%$ inhibition peak current at 0.1 and $10 \mu \mathrm{M}$, respectively).

result was obtained in three cells with $\mathrm{THCC}$, where there was a significant $(P<0.01)$ reduction in the percentage inhibition: $5 \pm 1 \%, 5 \pm 2 \%, 4 \pm 2 \%$, and $12 \pm 2 \%$ inhibition for 0.01 , $0.1,1$, and $10 \mu \mathrm{M}$ compared with control.

To verify further the possible involvement of a G-protein(s), neurons were dialyzed with the nonhydrolyzable GTP analog GDP- $\beta$-S $(500 \mu \mathrm{M})$, which inhibits the activation of G-proteins (Eckstein et al., 1979); initial experiments showed no effect of this compound on the $\mathrm{Ca}^{2+}$ channel current $(n=5)$. An example of the GDP- $\beta$-S diminution of the THCC inhibition of the $\mathrm{Ca}^{2+}$ current at $6 \%$ and $11 \%$ at 0.1 and $10 \mu \mathrm{M}$, respectively (compare with control, Fig. $8 C^{\prime}$ ), is illustrated in Figure $7 C$. The PES inhibition of the $\mathrm{Ca}^{2+}$ channel current was also significantly preventcd $(P<0.04)$ by GDP- $\beta$-S $(16 \%$ inhibition at $10 \mu \mathrm{M})$ (Fig. 8A). The PE inhibition of the $\mathrm{Ca}^{2+}$ channel current was only significantly reduced $(P<0.04)$ at 1 and $10 \mu \mathrm{M}$ by GDP$\beta$-S $(32 \%$ at $10 \mu \mathrm{M})$ compared with control (Fig. $8 B$ ). GDP- $\beta$-S also significantly prevented $(P<0.03)$ the THCC inhibition of the $\mathrm{Ca}^{2+}$ channel current (12\% inhibition at $10 \mu \mathrm{M}$ ) (Fig. $8 \mathrm{C}$ ).

\section{Involvement of $P K C$ with the neurosteroid action}

We concluded from these experiments that THCC, PES, and $\mathrm{PE}$ inhibited the $\mathrm{Ca}^{2+}$ channel current(s) via a G-protein-coupled mechanism. The modulation of $\mathrm{Ca}^{2+}$ channels by $\mathrm{G}$-protein-coupled receptors involves a variety of mechanisms. This mediation can be either by direct action of the activated $\alpha$-subunit (Brown and Birnbauer, 1988; Lipscombe et al., 1989; Toselli et al., 1989; Bernheim et al., 1991), or via intracellular modulators (for review, see Hille, 1992). Neurotransmitter release may also involve PKC activation (Rane et al., 1989; Diversé-Pierlussi and Dunlap, 1993) or the release of calcium from internal stores (Kramer et al., 1991). We did not directly test the latter, as our experiments were conducted in $3 \mathrm{~mm} \mathrm{Ba}{ }^{2+}$ with $5 \mathrm{mM} \mathrm{Cs}_{4}$-BAPTA for rapid buffering of any internal calcium, thus minimizing calcium-triggered internal calcium release (if any) as a second messenger involvement.

To determine whether THCC, PES, and PE activation of a $\mathrm{G}$-protein(s) and coupling to $\mathrm{Ca}^{2+}$ channels involved intracellular mediators such as PKC and the cAMP-dependent protein kinase (PKA), we first dialyzed neurons with broad-spectrum protein kinase inhibitors: $\mathrm{H}-7$, which is a nonspecific PKA and PKC inhibitor (Hidaka et al., 1984); staurosporine, a PKC inhibitor, which is also relatively nonselective (Ruëg and Burgess, 1989); and the synthetic 20 amino acid protein kinase inhibitor, which inhibits the phosphorylating units of cAMP-dependent kinase in skeletal muscle (Cheng et al., 1986).

Both staurosporine ( $400 \mathrm{nM} ; n=6$ cells per data point) and $\mathrm{H}-7$ ( $100 \mu \mathrm{M} ; n=4-6$ cells per data point) significantly diminished $(P<0.03)$ the THCC-induced $\mathrm{Ca}^{2+}$ channel current inhibition (12\% and $20 \%$ inhibition at $10 \mu \mathrm{M}$, respectively) (Fig. $9 \mathrm{~A}$; control data taken from Fig. $8 C$ ). Staurosporine ( $400 \mathrm{~nm}$; $n=4-5$ cells per data point) also significantly diminished the PES-induced $\mathrm{Ca}^{2+}$ channel current inhibition at $0.1 \mu \mathbf{M}(P<$ $0.04 ; 17 \%$ inhibition $), 1$ and $10 \mu \mathrm{M}(P<0.03 ; 22 \%$ and $29 \%$ inhihition, respectively) (Fig. $9 B)$. In $\mathrm{H}-7(100 \mu \mathrm{M} ; n=7$ cells per data point)-dialyzed neurons, the PES-induced $\mathrm{Ca}^{2+}$ current inhibition was only significantly $(P<0.04)$ diminished at 1 and $10 \mu \mathrm{M}(22 \%$ and $19 \%$ inhibition, respectively) (Fig. 9B). The PE-induced inhibition of the $\mathrm{Ca}^{2+}$ channel current was also significantly $(P<0.03)$ diminished by staurosporine $(n=3)$, where the amount of inhibition was $8 \pm 1 \%, 11 \pm 2 \%, 11 \pm$ $2 \%, 15 \pm 1 \%$, and $16.8 \pm 0.5 \%$ for $0.001,0.01,0.1,1$, and 10 $\mu \mathrm{M}$ PE, respectively (compare with control in Fig. $8 B$ ).

The 20 amino acid protein kinase inhibitor $(1 \mu \mathrm{M})$ significantly 
Figure 8. A G-protein mechanism couples the neurosteroid $\mathrm{Ca}^{2+}$ channel current inhibition. $A$, Pregnenolone sulfate. $B$, Pregnenolone. $C$, Allotetrahydrocorticosterone $(T H C C)$. Concentration-response curves were fitted according to logistic equation in Materials and Methods; control, inhibition of current in normal recording conditions by PES, PE, and THCC with $\mathrm{IC}_{50}$ values of $11 \mathrm{pm}, 130 \mathrm{pM}$, and $298 \mathrm{~nm}$ and $n H$ of $0.3,0.3$, and 0.7 , respectively $(n=$ $5-9$ cell per point). Neurons were isolated from PTX $(n=4-5$ cells per data point)-treated animals (1000 ng/24 hr for $48 \mathrm{hr}$; see Materials and Methods for details). GDP- $\beta$-S (500 $\mu \mathrm{M} ; n=5$ 6 cells per data point) was internally dialyzed through the patch pipette. PTX significantly reduced the PES, THCC $(P$ $<0.02)$, and $\mathrm{PE}(P<0.03) \mathrm{Ca}^{2+}$ channel current inhibition. GDP- $\beta-S$ also significantly reduced the $\operatorname{PES}(P<0.04)$, PE $(P<0.03)$, and THCC $(P<0.03)$ $\mathrm{Ca}^{2+}$ channel current inhibition.

diminished the THCC inhibition of the $\mathrm{Ca}^{2+}$ channel current $(P<0.03 ; n=4-5$ cells per point) (Fig. $9 \mathrm{~A})$. This protein kinase inhibitor also significantly diminished the PES $(P<0.03 ; n=$ 4-5 cells per point) inhibition of the $\mathrm{Ca}^{2+}$ channel current: $P<$ $0.02,16 \pm 3 \%$ inhibition at $0.01 \mu \mathrm{M} ; P<0.04,17 \pm 2 \%$ inhibition at $0.1 \mu \mathrm{M} ; P<0.02,20 \pm 3 \%$ inhibition at $1 \mu \mathrm{M}$, and $P<0.02,21 \pm 3 \%$ inhibition at $10 \mu \mathrm{M}$ (Fig. $9 B$ ).

These results suggested the involvement of protein phosphorylation involving PKC and/or PKA. However, as these compounds display a relatively nonselective for either $\mathrm{PKC}$ or PKA, we therefore examined the effects of the more recently available specific inhibitors of PKA and PKC.

We examined the effects of two specific inhibitors of $\mathrm{PKC}$ and one specific inhibitor of PKA on THCC and PE. A specific inhibitor of PKC, the synthesized pseudosubstrate inhibitor
B
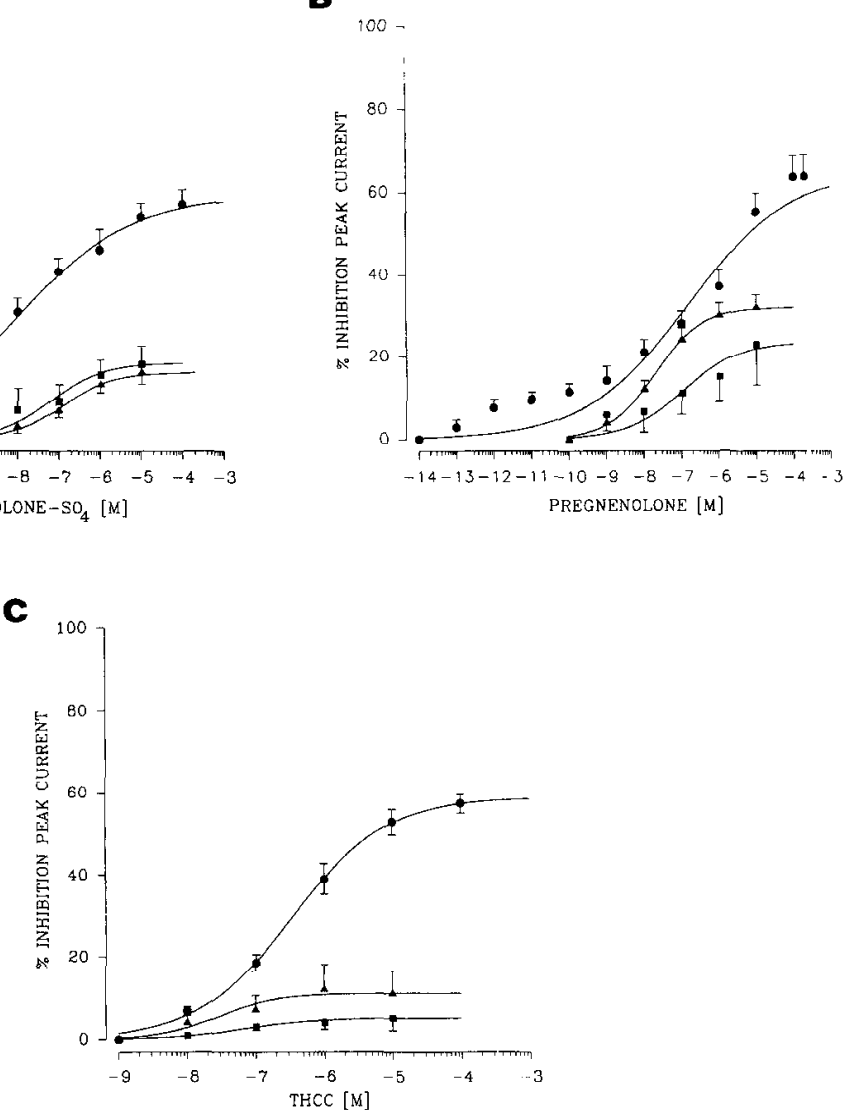

PKCI 19-36 (House and Kemp, 1987), is believed to be effective against all forms of PKC (Bell and Burns, 1991; Orr et al., 1992). Bisindolylmaleimide (BIS), a compound structurally related to staurosporine, is a potent and highly selective inhibitor of $\mathrm{PKC}$ (Toullec et al., 1991). As illustrated in Figure 10 A, internal dialysis of both BIS (1 $\mu \mathrm{M})$ and PKCI 19-36 (1 or $2 \mu \mathrm{M})$ significantly diminished $(P<0.02$, respectively) the THCC inhibition of the $\mathrm{Ca}^{2+}$ channel current. BIS also significantly diminished $(P<0.02)$ the PE inhibition of the $\mathrm{Ca}^{2+}$ channel current (Fig. $10 B)$. We next examined Rp-cAMPS, a specific membranepermcable, compctitive inhibitor of PKA that competes with cAMP for the binding site on the regulatory subunit of PKA, and the membrane-permeable analog of cAMP, Sp-cAMPS, which activates PKA (Dostmann et al., 1990 Frey et al., 1993). Inhibition of PKA by bath application of Rp-cAMPS ( $100 \mu \mathrm{M}$,

Table 1. Lack of effect of specific inhibitors of cAMP-dependent protein kinase on the THCC-induced $\mathrm{Ca}^{2+}$ channel current inhibition

\begin{tabular}{llllll} 
& \multicolumn{1}{l}{ THCC } & & \\
\cline { 2 - 6 } & $0.01 \mu \mathrm{M}$ & $0.1 \mu \mathrm{M}$ & $1 \mu \mathrm{M}$ & $10 \mu \mathrm{M}$ & $100 \mu \mathrm{M}$ \\
\hline Control & $7 \pm 2$ & $19 \pm 3$ & $38 \pm 7$ & $53 \pm 5$ & $57 \pm 3$ \\
Rp-cAMPS $(100 \mu \mathrm{M})$ & $(7)$ & $(8)$ & $(9)$ & $(7)$ & $(7)$ \\
& $6 \pm 2$ & $17 \pm 2$ & $36 \pm 2$ & $50 \pm 3$ & $54 \pm 4$ \\
Sp-cAMPS $(100 \mu \mathrm{M})$ & $(5)$ & $(6)$ & $(5)$ & $(5)$ & $(5)$ \\
& $6 \pm 3$ & $17 \pm 2$ & $38 \pm 2$ & $52 \pm 2$ & $56 \pm 3$ \\
& $(4)$ & $(4)$ & $(4)$ & $(4)$ & $(4)$
\end{tabular}

Data are the percentage inhibition of the peak $\mathrm{Ca}^{2+}$ channel current; control data were taken from Figure 8C. Rp-cAMPs (Rp-cyclic adenosine-3',5'-monophosphorothioate) and Sp-cAMPS (Sp-cyclic adenosine-3',5'-monophosphorothioate) were applied extracellularly. Values are means \pm SEM; numbers of cells are in parentheses. 


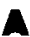

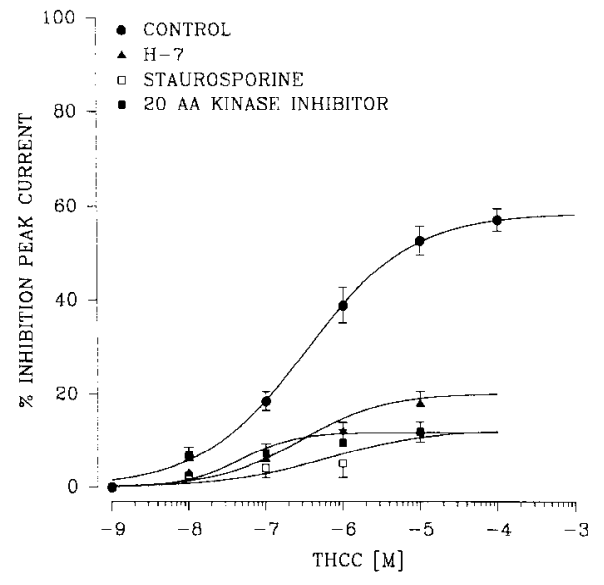

B

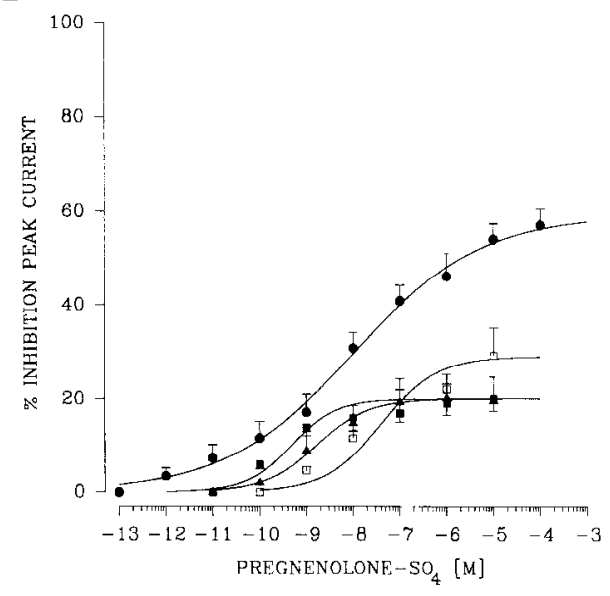

Figure 9. Effect of the broad-spectrum kinase inhibitors on the THCC and PES inhibition of the $\mathrm{Ca}^{2+}$ channel current. Control concentration-response curves are taken from Figure 8 , $A$ and $B$, for comparison; $\mathrm{H} 7(100 \mu \mathrm{M})$, staurosporine (400 nM) and the synthetic 20 amino acid protein kinase inhibitor (20 AA KINASE INHIBITOR) $(1 \mu \mathrm{M})$ were internally dialyzed through the patch pipette. $A$, THCC-induced $\mathrm{Ca}^{2+}$ channel current inhibition is significantly reduced $(P<0.03)$ by the kinase inhibitors. $B$, PES-induced $\mathrm{Ca}^{2+}$ channel current inhibition is also significantly reduced $(P<0.04)$. a concentration that inhibits late long-term potentiation in the hippocampal slice; Frey et al., 1993) showed no significant difference on either the THCC and PE inhibition of the $\mathrm{Ca}^{2+}$ channel current (Table 1 and Fig. $10 B$, respectively). Activation of PKA by bath application of Sp-cAMPS $(100 \mu \mathrm{M})$ also had no significant effect on the THCC (Table 1) or PF inhibition of the $\mathrm{Ca}^{2+}$ channel current (not shown; $n=4$ ). These results strongly suggested that both THCC and PE inhibited the $\mathrm{Ca}^{2+}$ channel current via activation of PKC.

\section{Discussion}

These results demonstrate that the neurosteroids THCC, PE, and PES have a potent, concentration-dependent inhibitory action on the HVA $\mathrm{Ca}^{2+}$ channel current in adult mammalian guinea pig hippocampal CA 1 neurons. These compounds inhibit only a fraction of the total whole-cell $\mathrm{Ca}^{2+}$ channel current; $\mathrm{PE}$ nonselectively inhibits both the $\mathrm{N}$ - and L-type $\mathrm{Ca}^{2+}$ channel current while THCC is primarily more selective for the N-type. This inhibition of the respective fractions of the $\mathrm{Ca}^{2+}$ channel current is mediated via a PTX-sensitive G-protein(s) mechanism associated with the activation of PKC.

\section{Steroid inhibition of the $\mathrm{Ca}^{2+}$ channel current}

The neurosteroids inhibited the whole-cell $\mathrm{Ca}^{2+}$ channel current with $\mathrm{IC}_{50}$ values in the nanomolar range (11-300 $\mathrm{nm}$ ). The isotherms gave Hill coefficients that suggested multiple binding sites. PES and PE inhibit the voltage-gated $\mathrm{Ca}^{2+}$ channel current in CAl neurons, with $\mathrm{IC}_{50}$ values of 11 and $130 \mathrm{~nm}$, respectively. In contrast, PES's inhibition of GABA-induced currents and potentiation of NMDA-induced currents (Wu et al., 1991; Bowlby, 1993) and increased intracellular calcium (Irwin et al., 1992) begins at concentrations $\geq 1 \mu \mathrm{M}$ in cultured neurons. While the progesterone metabolite allopregnanolone reversibly and dose dependently enhances the amplitude of the GABA-induced inward $\mathrm{Cl}^{-}$current over a range of 30-300 nm (Peters et al., 1988), it exerts a weaker inhibition of the voltage-gated $\mathrm{Ca}^{2+}$ channel current. To date, THCC has not been examined for any potential effects on GABA.
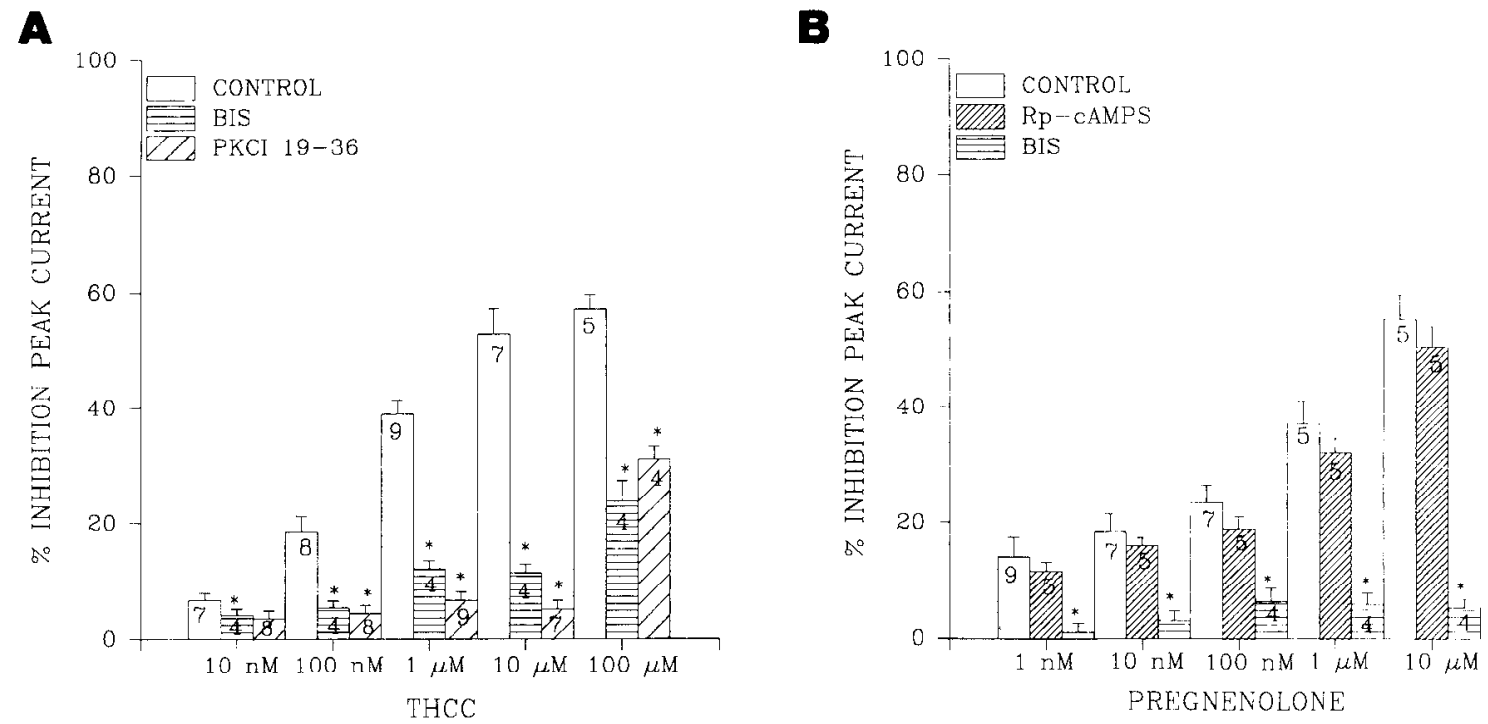

Figure 10. Neurosteroid inhibition of $\mathrm{Ca}^{2+}$ channel current involves activation of PKC. The specific PKC inhibitor bisindolylmaleimide (BIS) $(1 \mu \mathrm{M})$ and the pseudosubstrate inhibitor PKCI 19-36 (1 or $2 \mu \mathrm{M})$ were internally dialyzed through the patch pipette. The specific membranepermeable PKA inhibitor Rp-cyclic adenosine 3',5'-monophosphorothioate $(R p-c A M P S)$ was bath applied (100 $\mu \mathrm{M})$. Control data were taken from Figure 8. $A$, BIS and PKCI 19-36 significantly reduced $(*, P<0.02)$ the THCC inhibition of the $\mathrm{Ca}^{2+}$ channel current. $B$, BIS significantly reduced $(*, P<0.02)$ the PE inhibition of the $\mathrm{Ca}^{2+}$ channel current; Rp-cAMPS had no effect. 
The interaction of the steroids with the GABA receptor appears to be stereospecific (Harrison et al., 1986; Wu et al., 1990) and the structure-activity requirement for steroid interaction with the GABA and glycine receptors also appears to be different (Wu et al., 1990). A similar structure-activity relationship appears to exist on these neurons with regard to voltage-gated $\mathrm{Ca}^{2-}$ channels. Progesterone, which is derived from $\mathrm{PE}$ in brain, had no effect on the $\mathrm{Ca}^{2+}$ channel current in hippocampal CA1 neurons. Other studies have shown that progesterone enhances GABA-induced responses on Purkinje and spinal cord neurons (Smith et al., 1987; Wu et al., 1990), antagonizes glycine-induced responses (Wu ct al., 1990) and reversibly inhibits the nicotinic ACh response (Bertrand et al., 1991). PES and PE differ from progesterone at $\mathrm{C}-3$ in that there is a sulfate and an alcohol group, respectively, instead of a carbonyl group for progesterone. Furthermore, substitution of an acetate for the sulfate group on $P E$ resulted in complete loss of activity with regard to inhibition of the $\mathrm{Ca}^{2+}$ channel current. The fact that the acetate moiety is inactive suggests that the carbonyl is not sufficient to serve the same binding function as the hydroxyl or sulfate moiety. Interestingly, substitution of an acetate on allopregnanolone to give allopregnanolone acetate also showed no inhibitory action on the $\mathrm{Ca}^{2+}$ channel current.

The effect of certain neurosteroids on several parameters of $\mathrm{Ca}^{2+}$ channel gating indicated that there was a slowing of certain gating systems. Modulation of $\mathrm{Ca}^{2+}$ channel currents in numerous cell types is known to change both the time course and voltage dependence of $\mathrm{Ca}^{2+}$ currents (Carbonne and Swandulla, 1989). There was no change in the shape of the $I-V$ relationship by these compounds with maximal inhibition of the peak inward current at more negative step potentials. A similar voltage-dependent inhibition has been shown in dorsal root ganglion cells, where dynorphin and epinephrine inhibit the $\mathrm{Ca}^{2}+$ channel current more at negative than at positive potentials (Bean, 1989), and also for norepinephrine on superior cervical ganglion cells (Beech et al., 1992). THCC and PES did not alter the voltage dependence of activation of the $\mathrm{Ca}^{2 \cdots}$ channel current. A similar finding was reported in dorsal root ganglion cells, where the $\mathrm{GABA}_{\mathrm{B}}$ agonist (-)-baclofen inhibition of the $\mathrm{Ca}^{2}+$ channel current was not due to shift in the voltage dependence of channel availability (Dolphin and Scott, 1990). THCC and PES significantly slowed the rate of activation and deactivation of the $\mathrm{Ca}^{2+}$ channel current, which would suggest that these compounds bind and block the open (conducting) state of the $\mathrm{Ca}^{2+}$ channel(s). However, there was no use-dependent block by THCC, PE, and PES. Interestingly, the progesterone inhibition of the nicotinic $A C h$ current was also not mediated by an open channel block mechanism (Valera et al., 1992). The data suggest that the steroids bind to an extracellular receptor site on the cell membrane surface or a site within the lipid-protein interface as opposed to some site in the channel protein, and that modulation of the gating kinetics (slowing) could occur due to G-protein and/or intracellular mediators (see below). If PES depressed the $\mathrm{Ca}^{2+}$ channel current by perturbing the membrane structure or by binding to a hydrophobic region of the $\mathrm{Ca}^{2}+$ channel(s) bounded to a membrane lipid, then intracellular PES would strongly reduce the runup of the $\mathrm{Ca}^{2+}$ channel current under normal internal recording conditions. Additionally, intracellular PES would be expected to reduce dramatically the effect of externally applied PES. The lack of effect of internally dialyzed PES on the peak $\mathrm{Ca}^{2+}$ channel current, and that externally applied PES gave a comparable inhibition of the $\mathrm{Ca}^{2+}$ channel current with internal PES suggest that the steroid(s) can only access their binding site from the extracellular surface. Similar observations were made for the steroids alphaxalone and THDOC, where intracellular dialysis of these compounds had no effect on the GABA response (Lambert et al., 1990).

\section{$\mathrm{Ca}^{2+}$ channel type}

Guinea pig CAl neurons in this study have a whole-cell $\mathrm{Ca}^{2+}$ channel current consisting of three pharmacologically distinguished components, a CgTx-sensitive (N-type) current, a NIF (dihydropyridine)-sensitive (L-type) current, and a fraction resistant to both inhibitors (CgTX/NIF insensitive), similar to guinea pig CA3 (Mogul and Fox, 1991) and rat CA1 ncurons (Regan et al., 1991). This CgTX/NIF-insensitive current is also inhibited in these neurons ( $n=5$; not shown) by the toxin $\omega$-agatoxin-IVA, as previously reported by Mintz et al. (1992). None of these steroids inhibited the CgTX/NIF-insensitive or -resistant current. However, the data suggest that endogenous compounds can indeed inhibit particular fractions of the wholecell $\mathrm{Ca}^{2}$ " channel current. While PE had no effect on the resistant current, it was nonselective in that it inhibited both the CgTXand NIF-sensitive currents. THCC and allopregnanolone primarily inhibited a fraction of the $\mathrm{Ca}^{2+}$ channel current in the presence of NIF; however, in the presence of CgTX, THCC and allopregnanolone essentially inhibited no current. With long (200 msec) voltage steps, CgTX totally prevented the THCC inhibition of the $\mathrm{Ca}^{2+}$ current. Brief $(10 \mathrm{msec})$ voltage steps and tail current analysis further confirmed that THCC and CgTX inhibited the same fraction of $\mathrm{Ca}^{2}$ - channel current for THCC at $1 \mu \mathrm{M}$. However, CgTX did not completely occlude the THCC inhibition, because at higher concentrations of 10 and $100 \mu \mathrm{M}$, THCC showed an additional 19\% inhibition of the tail current amplitude. This additional inhibition in the presence of CgTX could account for the difference in the amount of inhibition seen under control conditions; that is, the maximal inhibition was $32 \%$ and $55 \%$ for $\mathrm{CgTX}$ and TIICC, respectively. Thus, while THCC primarily inhibits the N-type channel current, the data also imply a partial inhibition of the I-type channel current at higher concentrations. Typically, NIF exhibited a $40 \%$ inhibition of the peak $\mathrm{Ca}^{2+}$ current (see Fig. $6 \mathrm{~B}$, hatched bars) and showed a $30 \%$ inhibition in the presence of $1 \mu \mathrm{M}$ THCC (see Fig. $4 B$ ). This partial inhibition on the L-type by THCC is further verificd by lise complete lack of effect of THCC on the $\mathrm{CgTX} / \mathrm{NIF}$-insensitive current. In contrast to the maximal inhibition obtained by $100 \mu \mathrm{M}$ THCC, NIF $(100 \mu \mathrm{M})$ totally inhibits the $\mathrm{Ca}^{2+}$ channel current $(n=4 ; \mathrm{J}$. M. H. ffrench-Mullen, P. Danks, and K. T. Spence, unpublished observations). Indeed, NIF, which is commonly used to identify the L-type at 1-10 $\mu \mathrm{M}$, is nonselective in that at higher concentrations $(>10 \mu \mathrm{M})$ it will also inhibit other voltage-gated currents (Jones and Jacobs, 1990).

\section{$G$-protein mediation}

The actions of the neurosteroids THCC, PES, and PE on their respective $\mathrm{Ca}^{2+}$ channel current appear to be mediated through a PTX-sensitive G-protein(s) since their inhibitory effects were drastically reduced by intracellular dialysis of GDP- $\beta-S$ and by pretreatment with PTX. Because PTX blocks the actions of both $\mathrm{G} \alpha_{j}$ and $\mathrm{G} \alpha_{0}$ subclasses, the identity of the G-protein(s) and the specific subclasses cannot, at present, be determined from these data. Biochemical binding studies examining whether $G$-protein activation modulated the $\mathrm{Cg}$ TX recognition site using PTX and 
the specific antisera to $\mathrm{G} \alpha_{\mathrm{o}}$ suggested that this is the G-protein responsible (Bergamaschi et al., 1992). Thus, it is possible that $\mathrm{G} \alpha_{\mathrm{o}}$ is the same $\mathrm{G}$-protein responsible for the THCC inhibition of the $\mathrm{N}$-type $\mathrm{Ca}^{2+}$ current in these $\mathrm{CAl}$ neurons.

The modulation of $\mathrm{Ca}^{2+}$ channels by $\mathrm{G}$-proteins may involve a variety of mechanisms, including a direct action or via intracellular mediators, and more than one G-protein may be involved (Hille, 1992). There are many reports in the literature describing the actions of $\mathrm{PKC}$ and PKA activators and inhibitors on $\mathrm{Ca}^{2+}$ channel currents using the whole-cell recording technique (e.g., Doerner et al., 1988, 1990; Beech et al., 1992; Doerner and Alger, 1992; Diversé-Pierluissi and Dunlap, 1993). Specifically, with guinca pig hippocampal CAl neurons, using both dialyzed (whole cell) and undialyzed (nystatin-perforated patch technique) preparations, Doerner and Alger (1992) found that the depression of the $\mathrm{Ca}^{2+}$ current by PKC activators was indistinguishable between the two recording techniques. The involvement of PKC in transmitter modulation of neuronal $\mathrm{Ca}^{2+}$ channels has recently been reported for some systems (see Diversé-Pierlussi and Dunlap, 1993). In guinea pig hippocampal $\mathrm{CAl}$ neurons it has been shown that $\mathrm{PKC}$ regulates $\mathrm{Ca}^{2+}$ channels, where phorbol esters that activate $\mathrm{PKC}$ reversibly depressed the peak whole-cell $\mathrm{Ca}^{2+}$ current (Doerner and Alger, 1988, 1993; Doerner et al., 1988, 1990). The G-protein-dependent neurosteroid inhibition of $\mathrm{Ca}^{2+}$ channels appears to be coupled to an intracellular kinase mediator. The protein kinase inhibitors $\mathrm{H}-7$, staurosporine, and the 20 amino acid peptide inhibitor significantly reduced the THCC and PES inhibition of the $\mathrm{Ca}^{2+}$ channel current, which suggested the involvement of $\mathrm{PKC}$ and/or PKA. However, the more specific inhibitors of PKC, namely, PKCI 19-36 and BIS, significantly diminished the inhibitory effect of both THCC and PE. Rp-cAMPS, a specific competitive inhibitor of PKA, had no effect on the THCC and $\mathrm{PE}$ inhibition of the $\mathrm{Ca}^{2+}$ channel current, even at a concentration $(100 \mu \mathrm{M})$ known to inhibit late long-term potentiation in hippocampal slices (Frey et al., 1993). As it was previously reported that CAMP ( $1 \mathrm{~mm}$ ) slightly enhances the amplitude of the whole-cell $\mathrm{Ca}^{2+}$ current in acutely isolated hippocampal neurons (Doerner and Alger, 1988), we did not test cAMP directly. However, bath application of Sp-cAMPS to activate PKA had no effect on the THCC inhibition of the $\mathrm{Ca}^{2+}$ channel current.

These findings suggest that these neurosteroids inhibit and modify the gating properties of the CgTX-and NIF-sensitive $\mathrm{Ca}^{2+}$ channels via a PTX-sensitive G-protein(s) involving PKC activation. It is possible that THCC and PES may interact with the same or separate PTX-sensitive G-protein(s). An additional scenario is that THCC and PES may act through different G-proteins (or subclasses of one G-protein) to modulate the same $\mathrm{Ca}^{2+}$ current. For example, at least three different $\mathrm{G}$-proteins can transduce receptor-mediated inhibition of the $\mathrm{CgTX}$-sensitive $\mathrm{Ca}^{2+}$ channel current in NG108-15 cclls (Taussig ct al., 1992). The CgTX inhibition is direct and thus a relatively fast action, and THCC is indirect, slower to occur, and thus producing a more long-lasting effect.

In the hippocampus, the distribution of the N-type $\mathrm{Ca}^{2+}$ channels along CA1-CA3 pyramidal neurons is dense in the dendrites relative to the cell bodies (Westenbroek et al., 1992), and synaptic transmission involves activation of $\mathrm{CgTX}$-sensitive $\mathrm{Ca}^{2+}$ channels (Kamiya et al., 1988). L-type $\mathrm{Ca}^{2+}$ channels in hippocampus appear to be predominantly localized in cell bodies and the proximal portion of the dendrites on neurons (Westen- broek et al., 1990). THCC could feasibly have a more longlasting regulatory effect on synaptic transmission, as N-type channels are probably important contributors to the generation of dendritic action potentials. PES, while affecting synaptic transmission, would also have a major regulatory effect on L-type channels, mediating $\mathrm{Ca}^{2+}$ influx into cell bodies, hence having a dual regulatory role. The effects of THCC, PE, and PES on synaptic transmission remain to be explored.

\section{Physiological significance}

PE and PES are synthesized, and found in intact brain and glial cultures (Corpéchot et al., 1983; Lanthier and Patwardham, 1986). Steroid concentrations in the brain present temporal variations during physiological (such as the diurnal cycle) and pathophysiological (such as stress) conditions (for review, see Majewska, 1992). It is possible that the behavioral changes induced by neurosteroids (e.g., anxiolytic and anesthetic effects) may be related to modulation of receptor (GABA and NMDA) and/or ion channel $\left(\mathrm{Ca}^{2+}\right)$ activity. PES exhibits a wide range of effects on membrane channels that are selective, and differ for each particular channel type. PES potentiates NMDA currents (Wu et al., 1991; Irwin et al., 1992; Bowlby, 1993), depresses GABA and glycine currents (Mienville and Vicini, 1989; Majewska et al., 1990; Wu et al., 1990; Woodward et al., 1992), and inhibits $\mathrm{Ca}^{2+}$ channel currents (present study). These studies all suggest a rapid and direct action on a receptor, and with the exception of $\mathrm{Ca}^{2+}$ channel currents, PTX does not block the effect. Additionally, PES potentiation of NMDA occurs in both cell-attached and outside-out patch configurations, with a greater enhancement seen with cell-attached patches (Bowlby, 1993). Although a variety of in vitro actions for PE and PES are known, little data exist at the supracellular level. PES has been shown to modulate NMDA receptors in the intact animal by increasing the convulsant potency of NMDA but not pentylenetetrazol in mice, but when administered alone was unable to induce seizures (Maione et al., 1992). PES and PE have demonstrated memory-enhancing effects in mice over a wide dosage range (Flood et al., 1991). In man, a low dose (1 mg) of PE increased the amount of time spent in slow wave sleep and depressed the EEG power spectra, which was not associated with any changes in sleep-associated growth hormone and cortisol secretion (Steiger et al., 1993). While gross brain region tissue levels of PE and PES have been determined (Corpéchot et al., 1983), it is still unknown whether they are released into the extracellular space. It was recently shown that there were brain region-specific effects of neuroactive steroids on the affinity and density of the GABA-binding site (Jussofie, 1993). A similar situation might exist regarding the neurosteroid binding site for voltage-gated $\mathrm{Ca}^{2+}$ channels. These diverse actions, such as an enhancement of NMDA currents, depression of GABA/glycine currents, and depression of $\mathrm{Ca}^{2+}$ channel currents by PES, raise the possibility of a variety of functional roles, such as regulation of brain excitability. Inhibition of voltage-gated $\mathrm{Ca}^{2+}$ channel currents in combination with the modulation of the NMDA and GABA responses in specific brain regions could contribute to the sedative and anesthetic properties of these steroids. This depression of the $\mathrm{Ca}^{2+}$ channel currents may participate in the regulation of synaptic processes such as modulation of neuronal excitability, and modulation of neurotransmitter release-associated mechanisms.

In conclusion, these studies demonstrate that certain neurosteroids, acting via a PTX-sensitive G-protein-coupled mecha- 
nism involving PKC activation, are endogenous modulators of specific $\mathrm{Ca}^{2+}$ channel currents. Further studies are required to clarify the physiological and/or pathophysiological significance of the modulation of neuronal $\mathrm{Ca}^{2+}$ channels by steroids.

\section{References}

Baulieu EE, Robel P (1990) Neurosteroids: a new brain function. J Steroid Biochem Mol Biol 37:395-403.

Bean BP (1989) Neurotransmitter inhibition of neuronal calcium currents by changes in channel voltage dependence. Nature 340:153156.

Beech DJ, Bernheim L, Hille B (1992) Pertussis toxin and voltage dependence distinguish multiple pathways modulating calcium channels of rat sympathetic neurons. Neuron 8:97-106.

Bell R, Burns D (1991) Lipid activation of protein kinase C.J Biochem 266:4661-4664.

Bergamaschi S, Govini S, Battani F, Trabucchi M, Del Monaco S, Parenti M (1992) $G$ protein modulation of $\omega$-conotoxin binding sites in neuroblastoma $\times$ glioma NG $108-15$ hybrid cells. J Neurochem 59:536-543.

Bernheim L, Beech DJ, Hille B (1991) A diffusible second messenger mediates one of the pathways coupling receptors to calcium channels in rat sympathetic neurons. Neuron 6:859-867.

Bertrand D, Valera S, Bertrand S, Ballivet M, Rungger D (1991) Steroids inhibit nicotinic acetylcholine receptors. Neuroreport 2:277-280.

Bowlby MR (1993) Pregnenolone sulfate potentiation of $N$-methyl-Daspartate receptor channels in hippocampal neurons. Mol Pharmacol 43:813-819.

Brown AM, Birnbaumer L (1988) Direct G protein gating of ion channels. Am Phys Soc 254:H401-H410.

Byerly L, Yazejian B (1986) Intracellular factors for maintenance of calcium currents in perfused neurones from the snail, Lymnaea stagnalis. J Physiol (Lond) 370:631-650.

Carbonne E, Swandulla D (1989) Neuronal calcium channels: kinetics, blockade and modulation. Prog Biophys Mol Biol 54:31-58.

Carette B, Poulain P (1984) Excitatory effect of dehydroepiandrosterone, its sulfate ester and pregnenolone sulfate, applied by iontophoresis and pressure on single neurons in the septo-optic area of the guinca pig. Ncurosci Lett 45:205-2 10.

Cheng HC, Kemp BE, Pearson RB, Smith AJ, Misconi L, Van Patten SM, Walsh DA (1986) A potent synthetic peptide inhibitor of the cAMP-dependent protein kinase. J Biol Chem 261:989-992.

Corpéchot C, Robe P, Axelson M, Sjovall J, Baulieu EE (1981) Characterization and measurement of dehydroepiandrosterone sulfate in the rat brain. Proc Natl Acad Sci USA 78:4704-4708.

Corpéchot C, Synguelakis M, Talha S, Axelson M, Sjovall J, Vihko R, Baulieu EE, Robel P (1983) Pregnenolone and its sulfate ester in the rat brain. Brain Res 270:119-125.

Diversé-Pierlussi M, Dunlap K (1993) Distinct, convergent second messenger pathways modulate neuronal calcium currents. Neuron 10 : 753-760.

Doerner D, Alger BE (1988) Cyclic GMP depresses hippocampal Ca ${ }^{2+}$ current through a mechanism independent of cGMP-dependent pro tein kinase. Neuron 1:693-699.

Doerner D, Alger BE (1992) Evidence for hippocampal calcium channel regulation by PKC based on comparison of diacylglycerols and phorbol esters. Brain Res 597:30-40.

Doerner D, Pitler TA, Alger BE (1988) Protein kinase C activators block specific calcium and potassium current components in isolated hippocampal neurons. J Neurosci 8:4069-4078.

Doerner D, Abdel-Latif M, Rogers TB, Alger BE (1990) Protein kinase C-dependent and -independent effects of phorbol esters on hippocampal calcium channel current. J Neurosci 10:1699-1706.

Dolphin AC (1990) G protein modulation of calcium currents in neurons. Annu Rev Physiol 52:243-255.

Dolphin AC, Scott RH (1990) Activation of calcium channel currents in rat sensory neurons by large depolarizations: effect of guanine nucleotides and (-)-baclofen. Eur J Neurosci 2:104-108.

Dostmann WRG, Taylor SS, Genieser H-H, Jasteroff B, Døskeland SO, Dyreid D (1990) Probing the cyclic nucleotide binding sites of cAMPdependent protein kinases I and II with analogs of adenosine $3^{\prime}, 5^{\prime}$ cyclic phosphorothioates. J Biol Chem 265:10484-10491

Dutar P, Rascol O, Lamour Y (1989) w-Conotoxin GV1A blocks synaptic transmission in the CAl field of the hippocampus. Eur J Pharmacol 174:261-266.

Eckert R, Chad JE (1984) Inactivation of Ca channels. Prog Biophys Mol Biol 44:215-267.

Eckstein F, Cassel D, Levkovitz H, Lowe M, Selinger Z (1979) Guanosine $5^{\prime \prime}-O$-(2-thiodiphosphate). An inhibitor of adenylate cyclase stimulation by guanine nucleotides and fluoride ions. J Biol Chem 254:9829-9834.

ffrench-Mullen JMH, Rogawski MA (1992) Phencyclidine block of calcium currents in isolated guinea-pig hippocampal neurones. J Physiol (Lond) 456:85-105.

ffrench-Mullen JMH, Spence KT (1991) Neurosteroids block $\mathrm{Ca}^{2+}$ channel current in freshly isolated hippocampal $\mathrm{C} \Lambda 1$ neurons. Eur $\mathrm{J}$ Pharmacol 202:269-272.

ffrench-Mullen JMH, Barker JL, Rogawski MA (1993) Calcium current block by $(-)$-pentobarbilal, phenobarbital, and CHEB but not (+)-pentobarbital in acutely isolated hippocampal CA1 neurons: comparison with effects on GABA-activated $\mathrm{Cl}^{-}$current. J Neurosci 13:3211-3221.

Fisher RE, Gray R, Johnston D (1990) Properties and distribution of single voltage-gated calcium channels in adult hippocampal neurons. J Neurophysiol 64:91-103.

Flood JF, Morley JE, Roberts E (1992) Memory-enhancing effects in male mice of pregnenolone and steroids metabolically derived from it. Proc Natl Acad Sci USA 89:1567-1571.

Forscher P, Oxford GS (1985) Modulation of calcium channels by norepinephrine in internally dialyzed avian sensory neurons. J Gen Physiol 85:743-763.

Frey U, Huang Y-Y, Kandel ER (1993) Effects of cAMP simulate a late stage of LTP in hippocampal neurons. Science 260:1661-1664.

Gilman AG (1987) G proteins: transducers of receptor generated signals. Annu Rev Biochem 56:615-649.

Harrison NL, Majewska MD, Harrington JW, Barker JL (1987) Structure-activity relationship for steroid interaction with the gammaaminobutyric acid-A receptor complex. J Pharmacol Exp Ther 241: 346-352.

Hidaka H, Inagaki M, Kawamoto S, Saaki Y (1984) Isoquinolinesulfonamide, a novel and potent inhibitor of cyclic nucleotide-dependent protein kinase A and protein kinase C. Biochemistry 23:5036-5041.

Hille B (1992) G protein coupling mechanisms and nervous system signalling. Neuron 9:187-195.

House C, Kemp BE (1987) Protein kinase C contains a pseudosubstrate prototype in its regulatory domain. Science 238:1726-1728.

Irwin RP, Maragakis NJ, Rugawski MA, Purdy RH, Farb DH, Paul SM (1992) Pregnenolone sulfate augments NMDA receptor mediated increases in intracellular $\mathrm{Ca}^{2+}$ in cultured rat hippocampal neurons. Neurosci Lett 141:30-34.

Jones SW, Jacobs LS (1990) Dihydropyridine actions on calcium currents of frog sympathetic neurons. J Neurosci 10:2261-2267.

Jung-Testas I, Hu ZY, Robel P, Baulieu EE (1989) Biosynthesis of pregnenolone and progesterone in primary cultures of rat glial cells. Endocrinology 125:2083-2091

Jussofie A (1993) Brain region-specific effects of neuroactive steroids on the affinity and density of the GABA-binding site. Biol Chem Hoppe Seyler 374:265-270.

Kamiya H, Sawada S, Yamamoto C (1988) Synthetic omega-conotoxin blocks synaptic transmission in the hippocampus in vitro. Neurosci Lett 91:84-88.

Kramer RH, Kaczmarek LK, Levitan ES (1991) Neuropeptide inhibition of voltage-gated calcium channels mediated by mobilization of intracellular calcium. Neuron 6:557-563.

Lambert JJ, Hill-Vining C, Peters JA, Sturgess NC, Hales TG (1991) The actions of anaesthetic steroids on inhibitory and excitatory receptors. In: FIDIA RF Symposium Series, Vol 6 (Costa E, Barnard E, eds), pp 219-236. New York: Thieme.

Lanthier A, Patwardhan VV (1986) Sex steroids and 5-en-3 $\beta$-hydroxysteroids in specific regions of the human brain and cranial nerves. J Steroid Biochem 25:445-449.

Lipscombe D, Kongsamut S, Tsien RW (1989) Alpha-adrenergic inhibition of sympathetic neurotransmitter release mediated by modulation of N-type calcium-channel gating. Nature 340:639-642.

Maione S, Berrino L, Vitaglino S, Leyva J, Rossi F (1992) Pregnenolone sulfate increases the convulsant potency of $N$-methyl-D-aspartate in mice. Eur J Pharmacol 219:477-479.

Majewska MD (1992) Neurosteroids: endogenous bimodal modula- 
tors of the $\mathrm{GABA}_{4}$ receptor. Mechanism of action and physiological significance. Prog Neurobiol 38:379-395.

Majewska MD, Demirgoren S, Spivak CE, London ED (1990) The neurosteroid dehydroepiandrosterone sulfate is an allosteric antagonist of the GABA receptor. Brain Res 526:143-146.

McEwen BS (1991) Non-genomic and genomic effects of steroids on neural activity. Trends Pharmacol Sci 12:141-147.

Mienville J-M, Vicini S (1989) Pregnenolone sulfate antagonized GA$\mathrm{BA}_{\mathrm{A}}$ receptor-mediated currents via a reduction of channel opening frequency. Brain Res 489:190-194.

Miller R J (1987) Multiple calcium channels and neuronal function. Science 235:46-52.

Mint $z$ IA, Adams ME, Bean BP (1992) P-type calcium channcls in rat central and peripheral neurons. Neuron 9:85-95.

Mogul DJ, Fox AP (1991) Evidence for multiple types of $\mathrm{Ca}^{2 *}$ channels in acutely isolated hippocampal CA3 neurones of the guinea-pig. J Physiol (Lond) 433:259-281.

O'Dell TJ, Alger BE (1991) Single calcium channels in rat and guineapig hippocampal neurons. J Physiol (Lond) 436:739-767.

Orr J, Keranen L, Newton A (1992) Reversible exposure of the pseudosubstrate domain of protein kinase $C$ by phosphatidylserine and diacylglycerol. J Biol Chem 267:15263-15266.

Peters JA, Kirkness EF, Callachan H, Lambert JL, Turner AJ (1988) Modulation of the $\mathrm{GABA}_{\mathrm{A}}$ receptor by depressant barbiturates and pregnane steroids. Br J Pharmacol 94:1257-1269.

Plata-Salamán CR (1992) Interferons and central regulation of feeding. Am J Physiol 263:R 1222-R 1227.

Rane SG, Walsh MP, McDonald JR, Dunlap K (1989) Specific inhibitors of protein kinase $\mathrm{C}$ block transmitter-induced modulation of sensory calcium current. Neuron 4:269-280.

Regan LJ, Sah DWY, Bean BP (1991) Ca?' channels in rat central and peripheral neurones: high-threshold current resistant to dihydropyridine blockers and $\omega$-conotoxin. Neuron 6:269-280.

Ruëg UT, Burgess GM (1989) Staurosporine, K-252 and UCN-01: potent but nonspecific inhibitors of protein kinases. Trends Pharmacol Sci 10:218-220.

Scholz KP, Miller RJ (1991) GABA $_{B}$ receptor-mediated inhibition of Ca currents and synaptic transmission in cultured rat hippocampal neurones. J Physiol (Lond) 434:669-686.

Sher E, Clementi F (1991) Omega-conotoxin-sensitive voltage operated calcium channels in vertcbratc cells. Neuroscience 42:301-307.

Smith SS, Waterhouse BD, Woodward DJ (1987) Locally applied progesterone metabolites alter neuronal responsiveness in the cerebellum. Brain Res Bull 18:739-747.

Spence KT, Plata-Salaman CR, ffrench-Mullen JMH (1991) The neu- rosteroids pregnenolone and pregnenolone-sulfate but not progesteronc, block $\mathrm{Ca}^{2 \cdot+}$ currents in acutely isolated hippocampal CAl neurons. Life Sci 49:PL235-PL239.

Steiger A, Trachsel L, Guldner J, Hemmeter U, Rothe B, Rupprecht $R$, Vedder H, Holsboer $F$ (1993) Neurosteroid pregnenolone induces sleep-EEG changes in man compatible with inverse agonistic $\mathrm{GABA}_{\mathrm{A}^{-}}$ receptor modulation. Brain Res 615:267-274.

Swartz KJ, Bean BP (1992) Inhibition of calcium channels in rat CA3 pyramidal neurons by a metabotropic glutamate receptor. J Neurosci $12: 4358-4371$

Taussig R, Sanchez S, Rifo M, Gilman AG, Belardetti F (1992) Inhibition of the $\omega$-conotoxin-sensitive calcium current by distinct $\mathrm{G}$ proteins. Neuron 8:799-809.

Thompson SM, Wong RKS (1991) Development of calcium current subtypes in isolated rat hippocampal pyramidal cells. J Physiol (Lond) 439:671-689.

Toselli M, Lang J, Costa T, Lux HD (1989) Direct modulation of voltage-dependent calcium channels by muscarinic activation of a pertussis toxin-sensitive G-protein in hippocampal neurons. Pfluegers Arch 415:255-261.

Toullec D, Pianetti P, Coste H, Bcllevergue P, Grand-Perret T, Ajakanes $M$, Baudet $V$, Boissin $P$, Boursier E, Loriolle F, Duhamel L, Charon D, Kirilovsky J (1991) The bisindolylmaleimide GF 109203X is a potent and selective inhibitor of protein kinase C. J Biol Chem 266: $15771-15781$.

Valera S, Ballivet M, Bertrand D (1992) Progesterone modulates a neuronal nicotinic acetylcholine receptor. Proc Natl Acad Sci USA 89:9949-9953

Westenbroek RE, Ahlijanian MK, Catterall WA (1990) Clustering of L-type $\mathrm{Ca}^{2+}$ channels at the base of major dendrites in hippocampal pyramidal neurones. Nature 347:281-284.

Westenbroek RE, Hell JW, Warner C, Dubel SJ, Snutch TP, Catterall WA (1992) Biochemical properties and subcellular distribution of an N-type calcium channel $\alpha 1$ subunit. Neuron 9:1099-1115.

Woodward RM, Polenzani L, Miledi R (1993) Effects of steroids on $\gamma$-aminobutyric acid receptors expressed in Xenopus oocytes by poly $(\mathrm{A})^{+}$RNA from mammalian brain and retina. Mol Pharmacol 41:89-103.

Wu F-S, Gibbs TT, Farb DH (1990) Inverse modulation of gammaaminobutyric acid- and glycine-induced currents by progesterone. Mol Pharmacol 37:597-602

Wu F-S, Gibbs TT, Farb DH (1991) Pregnenolone sulfate: a positive allosteric modulator at the $N$-methyl-D-aspartate receptor. Mol Pharmacol 40:333-336. 